Systematic Review

\title{
The Impact of Genetic Variation on Sensitivity to Opioid Analgesics in Patients with Postoperative Pain: A Systematic Review and Meta-Analysis
}

\author{
Zhen-Yu Ren, MD, PhD', Xiao-Qing Xu, $\mathrm{PhD}^{1,4}$, Yan-Ping Bao, $\mathrm{PhD}^{3}$, Jia He, $\mathrm{PhD}^{2,3}$, \\ Le Shi, PhD' 2,3 , Jia-Hui Deng ${ }^{2,3}$, Xue-Jiao Gao, MS'2 Hui-Lin Tang, MS', Yu-Mei Wang, MD² and \\ Lin $\mathrm{Lu}, \mathrm{MD}, \mathrm{PhD}^{2,3}$
}

From: 'Department of Pharmacy, Peking University Third Hospital,

Beijing 100191, China; ${ }^{2}$ Peking

University Sixth Hospital/ Institute of Mental Health and Key Laboratory of Mental Health, Peking University, Beijing 100191, China; ${ }^{3}$ National Institute on Drug Dependence and Institute of Mental Health,

Peking University, Beijing

100191, China; ${ }^{4}$ Department

of Pharmacy Administration and Clinical Pharmacy, Peking

University Health Science Center,

Beijing 100191, China

Address Correspondence:

Prof. Lin Lu, MD, PhD

National Institute on Drug

Dependence and Institute of Mental Health

Peking University 38, Xue Yuan Road

Beijing 100191, China

E-mail: linlu@bjmu.edu.cn

Disclaimer: There was no external funding in the preparation of this manuscript. Conflict of interest: Each author certifies that he or she, or a member of his or her immediate family, has no commercial association (i.e., consultancies, stock ownership, equity interest, patent/licensing arrangements, etc.) that might pose a conflict of

interest in connection with the

submitted manuscript.

Manuscript received: 08-28-2014 Revised manuscript received: 10-13-2014

Accepted for publication: 11-17-2014

Free full manuscript: www.painphysicianjournal.com
Background: Individual response to opioid analgesics varies among patients.

Objective: This study sought to clarify the impact of distinct genetic variations on pain, opioid consumption, and opioid side effects in patients with postoperative pain.

Study Design: A systematic review and meta-analysis of associations between genetic singlenucleotide polymorphisms (SNPs) and opioids used for acute postoperative pain.

Setting: This meta-analysis examined all studies involving an association between genetic polymorphisms and the analgesic efficacy or clinical outcome of opioid analgesics for postoperative pain.

Methods: A literature search was performed up to January 31, 2014, using the PubMed, EMBase, ISI Web of Science, and Cochrane Library databases.

Results: Fifty-nine studies were included in this systematic review, and 23 studies (a total of 5,902 patients) were included in the final meta-analysis. The results showed that human $\mu$-opioid receptor gene (OPRM1) 118G allele variant carriers consumed more opioids for analgesia (SMD $=-0.17,95 \% \mathrm{Cl}=[-0.25,-0.10], P<0.00001)$, but reported higher pain scores $(\mathrm{MD}=-0.11$, $95 \% \mathrm{Cl}=[-0.17,-0.04], P=0.002$ ) and less nausea and vomiting (odds ratio $=1.30,95 \% \mathrm{Cl}=$ $[1.08,1.55], P=0.005)$ than the homozygous 118AA patients during the first 24 hour but not the 48 hour postoperative period. Moreover, CYP3A4* $1 \mathrm{G}$ carriers consumed less opioids than homozygous CYP3A4* $1 / * 1$ patients during the first 24 hours postoperative period $(M D=45.12$, $95 \% \mathrm{Cl}=[36.17,54.06], P<0.00001)$. No significant differences were found in CYP3A $5 * 3$, ABCB1 C3435T, and G2477T/A genetic polymorphisms.

Limitations: Some potential non-genetic factors can modify the effects of gene SNP on pain and opioid consumption during the postoperative period, such as age, gender, mood, anxiety, and drug-drug interactions. But further analyses could not be performed in the present meta-analysis due to limited information.

Conclusion: The results indicate that among the genetic SNPs we studied which include those affecting analgesic drug metabolism, transport of analgesic agents across the blood-brain barrier, and their activity at target receptors and ion channels and in the modulation of neurotransmitter pathways, the A118G allele variant of OPRM1 has the most potent influence on pain management of postoperative patients. Opioid receptor gene information may provide valuable information for clinicians to properly manage the analgesic use of opioids individually for better pain management.

Key words: Postoperative pain, meta-analysis, single-nucleotide polymorphism, opioid

Pain Physician 2015; 18:131-152 


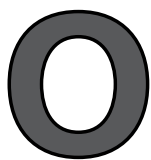

pioids are the most common analgesics used for moderate to severe pain. The sensitivity to pain and responses to analgesics, including analgesic effects and side effects, such as miosis, drowsiness, nausea, vomiting, constipation, and respiratory depression, are highly variable in patients. For example, morphine provides good analgesia without troublesome side effects for most patients. However, some patients experience either inadequate analgesia despite escalating doses or intolerable doselimiting side-effects (1-3). The amount of analgesic opioids that is used for postoperative pain control, even following the same surgery, also varies substantially among patients (4-6). Interindividual variability in the sensitivity to analgesic opioids has been explained mostly by genetic factors $(7,8)$. Therefore, providing conclusive evidence of the association between genetic variants and the analgesic effects of opioids is important. However, no meta-analyses of which we are aware have focused on the association between distinct gene polymorphisms and postoperative pain and opioid analgesics. A growing body of evidence in this field has made summarizing each candidate gene's contribution to postoperative analgesic and side effects difficult.

The present article summarizes the literature of genetic studies of postoperative pain to clarify the effects of genetic variants on pain, the analgesic effects of opioids, and adverse effects during the postoperative period in patients with postoperative pain.

\section{Methods}

\subsection{Literature Search Strategy}

We performed a systematic search of PubMed (1970 to January 31, 2014), EMBase (1966 to January $31,2014)$, ISI Web of Science (1899 to January 31, 2014), and the Cochrane Library (1996 to January 31, 2014) for all studies that showed an association between genetic polymorphisms and the analgesic efficacy or clinical outcome of opioid analgesics using the following search combinations: "gene," "genetic," "polymorphism," "postoperative pain," "postoperative analgesia." The bibliographies of the identified original papers or review articles were also retrieved to provide a complete literature search.

\subsection{Data Selection}

Four researchers (ZY Ren, XQ Xu, J He, and L Shi) independently assessed the articles for their eligibility for inclusion. Studies were included if they were random- ized or cohort studies in perioperative patients who took opioids for analgesia and presented the results of at least one of the following endpoints stratified by genetic polymorphisms: (i) pain score, (ii) opioid dosage requirements and typical clinical effects of opioids subdivided into (iii) analgesia and so-called side effects, including (iv) respiratory depression, (v) psychotropic effects, such as sedation, (vi) tolerance or addiction to opioid analgesics, (vii) nausea and vomiting, (viii) constipation, and (ix) "other side effects," such as blurred vision, decreases in heart rate or blood pressure, and itching. Different $\mu$-opioid agonists and patient populations who underwent surgery (Table 1 ) were included in the meta-analysis. If the same patient population was used in more than one publication, then only the final dataset was chosen to avoid data replication.

\subsection{Data Extraction}

The data were independently extracted from eligible papers by 4 researchers (ZY Ren, XQ Xu, J He, and $L$ Shi) who subsequently cross-checked the data and resolved discrepancies. When data were reported in a format that did not allow inclusion in the metaanalysis, the authors of those papers were contacted directly and asked to release the data. For each study, the following data were extracted: first author, year of publication, number of patients, age, gender, genetic variants, setting, analgesic opioids use information, and clinical outcome. We determined whether the genotype frequencies agreed with Hardy-Weinberg equilibrium by calculating the $\chi^{2}$ goodness-of-fit. If the data were not provided in a tabular format, then they were calculated from the corresponding paragraphs or supplementary appendices. Any disagreements were resolved by further discussion or consultation.

The endpoints of our meta-analysis included pain score, opioid consumption, and side effects during the first 24 or 48-hour postoperative period. The detailed process of identifying eligible studies and the reasons for exclusion are presented in Fig. 1. Because only a limited number of studies involved side effects other than nausea and vomiting, the endpoint for side effects in the present analysis included only nausea and vomiting.

\subsection{Statistical Analysis}

The data were extracted from each individual study and pooled using Review Manager 5.1.0 to calculate the mean difference (MD), standard mean difference (SMD), and odds ratio (OR) as the parameters of pain score, opioid consumption, and drug side effects, 
Table 1. Characteristics of the studies included in the meta-analysis.

\begin{tabular}{|c|c|c|c|c|c|c|c|c|}
\hline No. & $\begin{array}{l}\text { Author } \\
\text { (year) }\end{array}$ & $\begin{array}{l}\text { Male/ } \\
\text { Female }\end{array}$ & $\begin{array}{l}\begin{array}{l}\text { Age } \\
\text { (years) }\end{array} \\
\text { (year }\end{array}$ & Setting & $\begin{array}{l}\text { Hardy- } \\
\text { Weinberg }\end{array}$ & Variant & $\begin{array}{l}\text { Opioid } \\
\text { administered }\end{array}$ & $\begin{array}{l}\text { Clinical } \\
\text { adverse } \\
\text { events } \\
\text { (no.) }\end{array}$ \\
\hline 1 & $\begin{array}{l}\text { Sia et al. } \\
(2008)(6)\end{array}$ & $0 / 585$ & $\begin{array}{l}32.5 \\
(4.7)\end{array}$ & $\begin{array}{l}\text { Post cesarean } \\
\text { analgesia }\end{array}$ & No & OPRM1 A118G & morphine & $\begin{array}{l}\text { nausea, } 40 \\
\text { vomiting, } \\
32\end{array}$ \\
\hline 2 & $\begin{array}{l}\text { Mamie et } \\
\text { al. (2013) } \\
(42)\end{array}$ & $51 / 117$ & 11.4 & $\begin{array}{l}\text { orthopedic or } \\
\text { abdominal surgery }\end{array}$ & Yes & $\begin{array}{l}\text { OPRM1 A118G } \\
\text { ABCB1 C3435T } \\
\text { COMT Val158Met } \\
\text { NTRK1 His40Tyr POMC } \\
\text { Arg236Gln CYP2D6 }\end{array}$ & morphine & ND \\
\hline 3 & $\begin{array}{l}\text { Hayashida } \\
\text { et al. } \\
(2008)(31)\end{array}$ & $79 / 59$ & $\begin{array}{l}63.1 \\
(9.8)\end{array}$ & $\begin{array}{l}\text { major open } \\
\text { abdominal surgery }\end{array}$ & Yes & $\begin{array}{l}\text { OPRM1 A118G } \\
\text { OPRM1 IVS2+G691C } \\
\text { OPRM1 IVS3+G5953A } \\
\text { OPRM1 IVS3+A8449G } \\
\text { OPRM1 TAA+A2109G }\end{array}$ & $\begin{array}{l}\text { fentanyl and } \\
\text { morphine }\end{array}$ & ND \\
\hline 4 & $\begin{array}{l}\text { Zhang et } \\
\text { al. (2010b) } \\
(24)\end{array}$ & $0 / 174$ & $\begin{array}{l}41.1 \\
(5.5)\end{array}$ & $\begin{array}{l}\text { total abdominal } \\
\text { hysterectomy or } \\
\text { myomectomy }\end{array}$ & Yes & OPRM1 A118G & remifentanil & $\begin{array}{l}\text { nausea and } \\
\text { vomiting, } \\
48\end{array}$ \\
\hline 5 & $\begin{array}{l}\text { Chou et } \\
\text { al. }(2006 \mathrm{~b}) \\
(20)\end{array}$ & $31 / 89$ & $\begin{array}{l}63.3 \\
(10.9)\end{array}$ & total knee arthroplasty & No & OPRM1 A118G & morphine & $\begin{array}{l}\text { nausea, } 7 \\
\text { vomiting, } \\
22\end{array}$ \\
\hline 6 & $\begin{array}{l}\text { Fukuda et } \\
\text { al. (2010) } \\
(30)\end{array}$ & $40 / 68$ & $\begin{array}{l}25.7 \\
(6.7)\end{array}$ & $\begin{array}{l}\text { sagittal split } \\
\text { mandibular } \\
\text { osteotomy }\end{array}$ & Yes & $\begin{array}{l}\text { OPRM1 A118G } \\
\text { OPRM1 IVS2+G691C } \\
\text { OPRM1 IVS3+G5953A } \\
\text { OPRM1 IVS3+A8449G } \\
\text { OPRM1 TAA+A2109G }\end{array}$ & fentanyl & ND \\
\hline 7 & $\begin{array}{l}\text { Coulbault } \\
\text { et al. } \\
(2006)(5)\end{array}$ & $44 / 30$ & $56(12)$ & $\begin{array}{l}\text { abdominal surgery } \\
\text { with a colorectal or } \\
\text { coloanal anastomosis }\end{array}$ & Yes & $\begin{array}{l}\text { OPRM1 A118G } \\
\text { ABCB1 G2677T/A } \\
\text { ABCB1 C3435T } \\
\text { UGT2B7 T802C }\end{array}$ & morphine & $\begin{array}{l}\text { nausea and } \\
\text { vomiting, } \\
23\end{array}$ \\
\hline 8 & $\begin{array}{l}\text { Zwisler et } \\
\text { al. (2011) } \\
(27)\end{array}$ & $38 / 228$ & 51.2 & $\begin{array}{l}\text { thyroidectomy (partial } \\
\text { and complete), } \\
\text { parathyroidectomy, } \\
\text { mastectomy, and } \\
\text { hysterectomy (vaginal } \\
\text { and abdominal) }\end{array}$ & Yes & $\begin{array}{l}\text { OPRM1 A118G } \\
\text { ABCB1 C3435T } \\
\text { ABCB1 G2677T/A }\end{array}$ & $\begin{array}{l}\text { alfentanil or } \\
\text { sufentanil or } \\
\text { oxycodone }\end{array}$ & $\begin{array}{l}\text { nausea/ } \\
\text { vomiting } \\
\text { AUC } 0-24 \\
\text { h, } 0.2\end{array}$ \\
\hline 9 & $\begin{array}{l}\text { Tan et al. } \\
(2009)(38)\end{array}$ & $0 / 994$ & $\begin{array}{l}32.5 \\
(4.8)\end{array}$ & $\begin{array}{l}\text { elective caesarean } \\
\text { delivery }\end{array}$ & Yes & $\begin{array}{l}\text { OPRM1 A118G } \\
\text { OPRM1 -T172G }\end{array}$ & morphine & $\begin{array}{l}\text { vomiting, } \\
123\end{array}$ \\
\hline 10 & $\begin{array}{l}\text { Zhang et } \\
\text { al. (2011) } \\
(25)\end{array}$ & $0 / 165$ & $25-50$ & $\begin{array}{l}\text { undergoing elective } \\
\text { total abdominal } \\
\text { hysterectomy or } \\
\text { myomectomy under } \\
\text { general anesthesia }\end{array}$ & Yes & OPRM1 A118G & remifentanil & $\begin{array}{l}\text { nausea, } 47 \\
\text { vomiting, } \\
27\end{array}$ \\
\hline 11 & $\begin{array}{l}\text { Chou et al. } \\
(2006 a)(4)\end{array}$ & $0 / 80$ & $\begin{array}{l}45.7 \\
(6.7)\end{array}$ & $\begin{array}{l}\text { abdominal total } \\
\text { hysterectomy }\end{array}$ & No & OPRM1 A118G & morphine & $\begin{array}{l}\text { vomiting, } \\
12\end{array}$ \\
\hline 12 & $\begin{array}{l}\text { Sia et al. } \\
(2013)(22)\end{array}$ & $0 / 973$ & $\begin{array}{l}47.8 \\
(5.4)\end{array}$ & $\begin{array}{l}\text { abdominal } \\
\text { hysterectomy }\end{array}$ & Yes & OPRM1 A118G & morphine & ND \\
\hline 13 & $\begin{array}{l}\text { Zhang et } \\
\text { al. (2013) } \\
(23)\end{array}$ & $76 / 52$ & $\begin{array}{l}52.5 \\
(12.6)\end{array}$ & radical gastrectomy & Yes & OPRM1 A118G & fentanyl & $\begin{array}{l}\text { nausea } 47 \\
\text { vomiting } 27\end{array}$ \\
\hline 14 & $\begin{array}{l}\text { Liao et al. } \\
(2013)(21)\end{array}$ & $60 / 37$ & $\begin{array}{l}52.3 \\
(13.1)\end{array}$ & radical gastrectomy & Yes & $\begin{array}{l}\text { OPRM1 A118G } \\
\text { CYP3A4*18B }\end{array}$ & fentanyl & $\begin{array}{l}\text { nausea, } 37 \\
\text { vomiting, } \\
18\end{array}$ \\
\hline
\end{tabular}


Table 1 (cont.). Characteristics of the studies included in the meta-analysis.

\begin{tabular}{|c|c|c|c|c|c|c|c|c|}
\hline No. & $\begin{array}{l}\text { Author } \\
\text { (year) }\end{array}$ & $\begin{array}{l}\text { Male/ } \\
\text { Female }\end{array}$ & $\begin{array}{l}\text { Age } \\
\text { (years) }\end{array}$ & Setting & $\begin{array}{l}\text { Hardy- } \\
\text { Weinberg }\end{array}$ & Variant & $\begin{array}{l}\text { Opioid } \\
\text { administered }\end{array}$ & $\begin{array}{l}\text { Clinical } \\
\text { adverse } \\
\text { events } \\
\text { (no.) } \\
\end{array}$ \\
\hline 15 & $\begin{array}{l}\text { Kim et al. } \\
(2013)(32)\end{array}$ & $0 / 196$ & $\begin{array}{l}45.3 \\
(4.9)\end{array}$ & $\begin{array}{l}\text { abdominal } \\
\text { hysterectomy or } \\
\text { laparoscopic assisted } \\
\text { vaginal hysterectomy }\end{array}$ & Yes & $\begin{array}{l}\text { OPRM1 A118G } \\
\text { ABCB1 } 2677 \mathrm{G}>\mathrm{A} / \mathrm{T} \\
\text { ABCB1 } 3435 \mathrm{C}>\mathrm{T} \\
\text { CYP3A4*18 } \\
\mathrm{CYP} 3 A 5 * 3\end{array}$ & fentanyl & ND \\
\hline 16 & $\begin{array}{l}\text { Boswell et } \\
\text { al. (2013) } \\
\text { (35) }\end{array}$ & $0 / 158$ & $\begin{array}{l}27.6 \\
(5.9)\end{array}$ & cesarean section & ND & OPRM1 A118G & $\begin{array}{l}\text { hydrocodone/ } \\
\text { morphine }\end{array}$ & $\begin{array}{l}\text { nausea, } 33 \\
\text { vomiting, } 7\end{array}$ \\
\hline 17 & $\begin{array}{l}\text { Kolesnikov } \\
\text { et al. (2011) } \\
(151)\end{array}$ & $45 / 57$ & $\begin{array}{l}54.6 \\
(11.1)\end{array}$ & $\begin{array}{l}\text { abdominal radical } \\
\text { prostatectomy or } \\
\text { hysterectomy }\end{array}$ & $\begin{array}{l}\text { OPRM1 } \\
\text { No } \\
\text { COMT Yes } \\
\end{array}$ & $\begin{array}{l}\text { OPRM1 A118G } \\
\text { COMT Val158Met }\end{array}$ & morphine & ND \\
\hline 18 & $\begin{array}{l}\text { Chen et al. } \\
(2013)(45)\end{array}$ & $0 / 129$ & ND & $\begin{array}{l}\text { total abdominal } \\
\text { hysterectomy }\end{array}$ & Yes & OPRM1 A118G & morphine & $\begin{array}{l}\text { nausea, } 81 \\
\text { vomiting, } \\
58\end{array}$ \\
\hline 19 & $\begin{array}{l}\text { Yuan et al. } \\
\text { (2011)(61) }\end{array}$ & $83 / 93$ & $\begin{array}{l}45.9 \\
(11.1)\end{array}$ & $\begin{array}{l}\text { lower abdominal } \\
\text { surgery }\end{array}$ & Yes & CYP 3 A $4^{\star} 1 G$ & fentanyl & $\begin{array}{l}\text { nausea and } \\
\text { vomiting, } \\
50\end{array}$ \\
\hline 20 & $\begin{array}{l}\text { (Zhang et } \\
\text { al. (2010a) } \\
(73)\end{array}$ & $0 / 143$ & $406(6.0)$ & $\begin{array}{l}\text { abdominal total } \\
\text { hysterectomy or } \\
\text { myomectomy }\end{array}$ & Yes & CYP 3 A $4{ }^{*} 1 \mathrm{G}$ & fentanyl & $\begin{array}{l}\text { nausea and } \\
\text { vomiting, } \\
41\end{array}$ \\
\hline 21 & $\begin{array}{l}\text { Slanar et } \\
\text { al. }(2012) \\
(51)\end{array}$ & $0 / 156$ & $\begin{array}{l}39.6 \\
(14.2)\end{array}$ & knee arthroscopy & Yes & $\begin{array}{l}\text { CYP2D6 MDR1 } \\
\text { ABCB1 C3435T }\end{array}$ & tramadol & $\begin{array}{l}\text { nausea and } \\
\text { vomiting, } 6\end{array}$ \\
\hline 22 & $\begin{array}{l}\text { Sia et al. } \\
(2010)(86)\end{array}$ & $0 / 620$ & $\begin{array}{l}32.4 \\
(4.7)\end{array}$ & caesarean section & Yes & $\begin{array}{l}\text { ABCB1 C3435T } \\
\text { ABCB1 C1236T } \\
\text { ABCB1 G2677T/A }\end{array}$ & morphine & $\begin{array}{l}\text { nausea, } 44 \\
\text { vomiting, } \\
36\end{array}$ \\
\hline 23 & $\begin{array}{l}\text { (Candiotti } \\
\text { et al. } \\
\text { (2013) (88) }\end{array}$ & $94 / 58$ & $\begin{array}{l}53.7 \\
(16.3)\end{array}$ & nephrectomy & Yes & $\mathrm{ABCB} 1 \mathrm{C} 3435 \mathrm{~T}$ & $\begin{array}{l}\text { morphine/ } \\
\text { oxycodone }\end{array}$ & ND \\
\hline
\end{tabular}

respectively. We calculated the SMD to standardize the data, such as when opioid consumption was represented in different units. Candidate genes for the review and meta-analysis were selected if $\mathbf{2}$ or more studies evaluated the data and such data were available. Individual and pooled results are illustrated as point estimates and $95 \%$ confidence intervals (Cls), with 2-sided $P$ values using a fixed-effects model or random-effects model based on heterogeneity. A $P$ value $<0.05$ was considered statistically significant. Heterogeneity across all of the included studies was assessed by the Q-statistic, with a $P<0.05$ or $1^{2}>50 \%$ considered significant heterogeneity.

\section{Review and Meta-Anulysis Results}

\subsection{Human $\mu$-opioid Receptor Gene (OPRM1)}

Three opioid receptors $(\mu, \delta$, and $\kappa)$ are involved in numerous biological processes. The $\mu$-opioid receptor (MOR), a member of the G-protein-coupled receptor superfamily, has been identified as the major site of the analgesic action of opiate drugs. Animal studies have indicated that MOR gene knockout mice present morphine-induced analgesic inefficacy (9). In humans, variations in the MOR gene also affect opiate-related analgesia $(10,11)$. Among over 3,000 polymorphisms in OPRM1 (www.1000genomes.org), the most commonly studied single-nucleotide polymorphism (SNP) is $A 118 G$, which leads to a substitution of the amino acid asparagine to aspartate at position 40 . Therefore, the SNP of the human MOR gene (OPRM1) (12), which is located on human chromosome $6 q 24-q 25$, has been investigated for its clinical value in pain modulation (7).

\subsubsection{A118G and Postoperative Pain}

A118G variation eliminates a putative $\mathrm{N}$-linked 


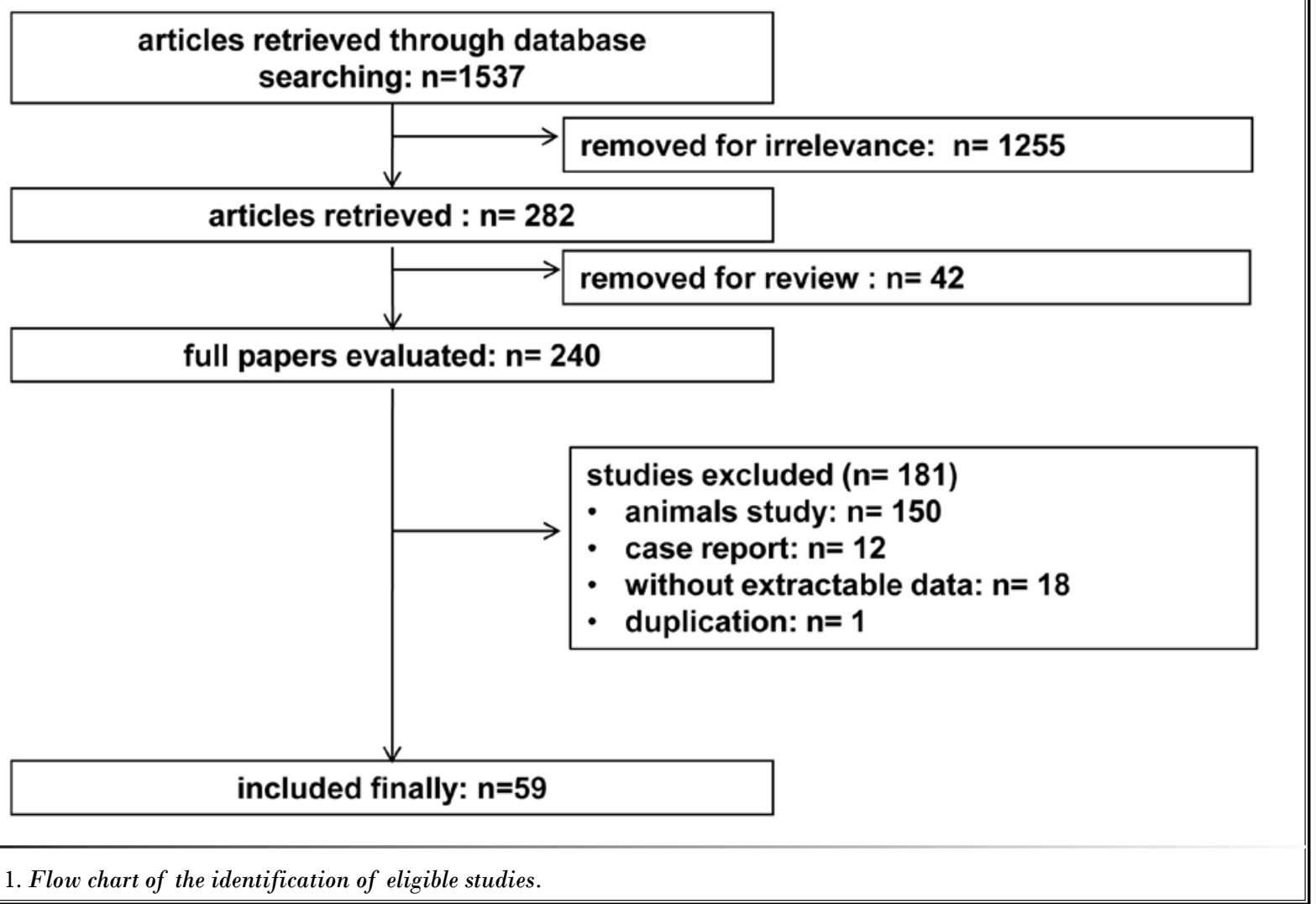

glycosylation site in the receptor (13) and affects the ligand-receptor binding process, which is regarded as the mechanism that underlies discrepancies in the sensitivity to analgesic opioids, such as pain sensitivity (14) and analgesic requirements (15-17). Moreover, the frequency of the polymorphism (the $G$ allele) varies depending on the population that is studied, from $16 \%$ in northern and western Europeans to $46.5 \%$ in Asians (NCBI HapMap SNP frequency data available at: www. ncbi.nlm.nih.gov/projects/SNP/snp_ref.cgi?rs=1799971). Emerging evidence suggests the clinical relevance (15) and therapeutic predictive value (18) of SNPs of OPRM1, and inclusion of the OPRM1 variant 118A>G into concepts of personalized therapeutic pain management has been increasingly contemplated. A previous metaanalysis assessed the OPRM1 118A>G genetic variant and the analgesic effects of opioids on patients with various pain, including acute postoperative pain, chronic non-cancer pain, and cancer pain, but reported no statistically significant association between the OPRM1 $118 \mathrm{~A}>\mathrm{G}$ polymorphism and pain or opioid dosing (19). To our knowledge, no meta-analysis has focused on the association between the OPRM1 A118G SNP and analgesic opioid consumption in acute postoperative pain.

Meta-analysis of A118G and pain scores: Pain score data were available from independent samples in 8 studies for the AA vs. G variation during the 24hour postoperative period $(4,6,20-25)$ and four studies during the 48 -hour postoperative period $(4,20,21,23)$. Two studies were excluded because the pain scores were either in the form of AUC0-24-hour or median and semi-interquartile range (26,. The study by $\mathrm{Wu}$ and co-workers (28) was excluded because the pain scores were obtained after bolus fentanyl. Two other studies were excluded because they lacked data from the specific postoperative period (i.e., 24 or 48 hour) $(26,29)$. The final analysis included 1,004 homozygous 118AA patients and 1,318 $118 \mathrm{G}$ allele carriers during the 24-hour postoperative period and 213 homozygous 118AA patients and $212118 \mathrm{G}$ allele carriers during the 48-hour postoperative period. Actual 24-hour pain was reported using ordinal scales (11 points, ranging from 0 for no pain to 10 for maximum pain) in most of the studies. The pain scores were transformed to 11 points 


\section{A 24-h postoperative}

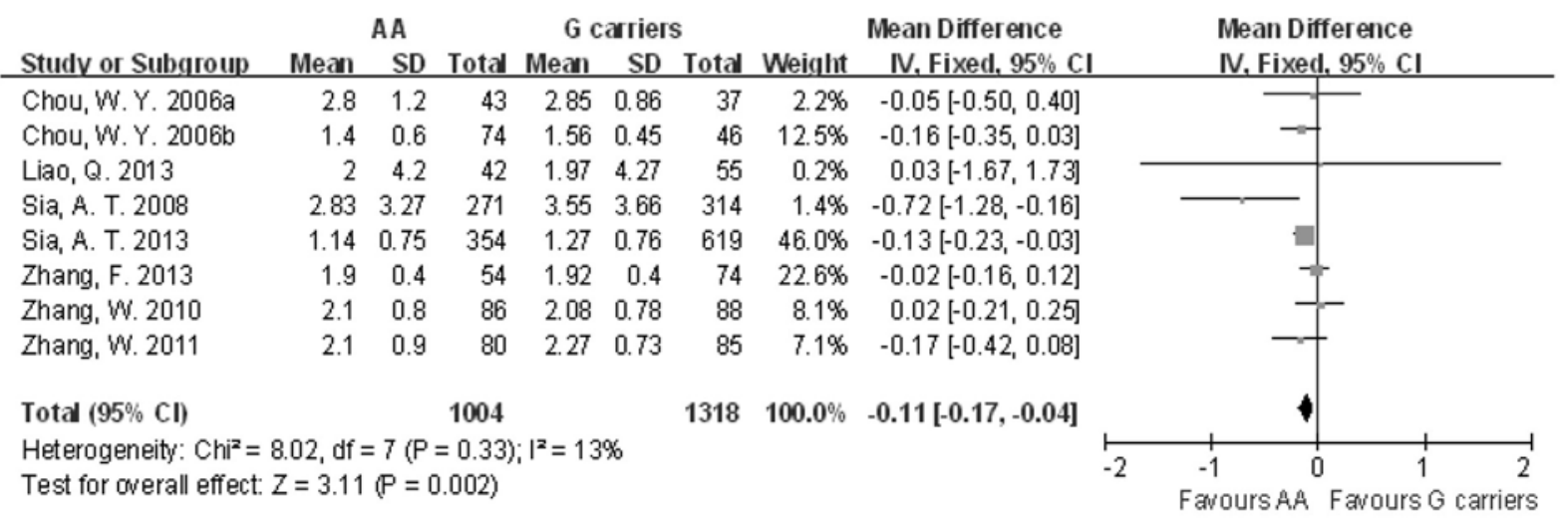

\section{B 48-h postoperative}

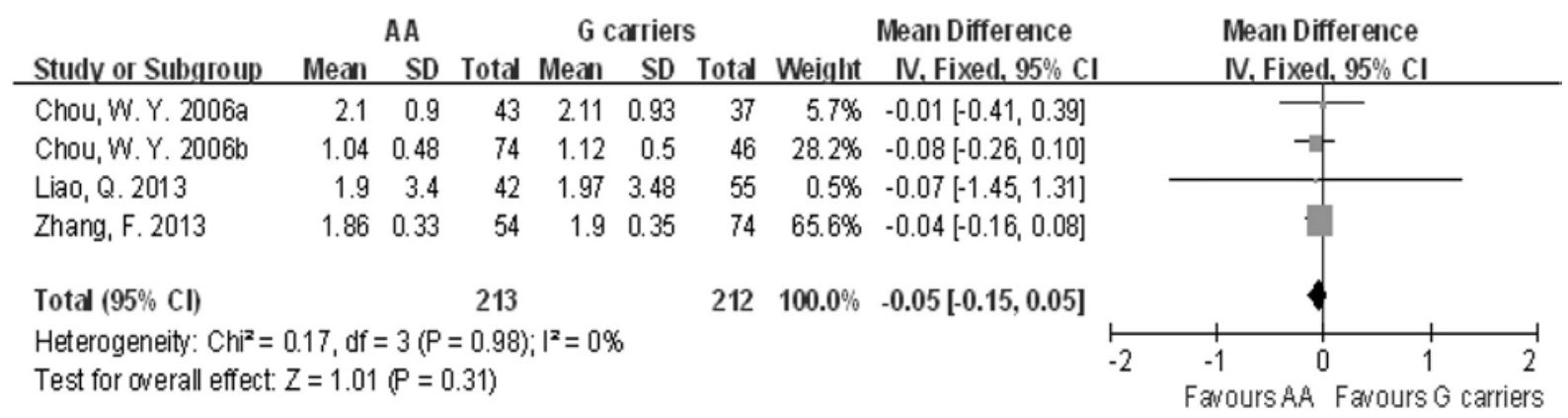

Fig. 2. Pain scores in OPRM1 118 G allele carriers vs. 118 AA patients during the 24 hour (A) and 48 hour (B) postoperative period. (A) Pain scores in the $118 G$ allele carrier group were higher than in $118 A$ A patients (MD $=-0.11,95 \% C I=[-0.17$, $-0.04 \mathrm{~J}, P=0.002)$. (B) No significant difference in pain scores was found between the 2 groups $(M D=-0.05,95 \% C I=$ $[-0.15,0.05], P=0.31)$. No heterogeneity was found across all of the studies $(P>0.05)$.

if the original data were presented on a 100-point scale, ranging from 0 for no pain to 100 for maximum pain.

Heterogeneity was not detected across studies $\left(\chi^{2}\right.$, $P>0.05$; Fig. 2A, B), so a fixed-effect model was chosen. Presence of the $G$ allele was associated with higher pain scores compared with AA homozygotes during the first 24-hour postoperative period (fixed-effects model: MD $=-0.11,95 \% \mathrm{Cl}=-0.17,-0.04, P=0.002$; Fig. 2A). No significant difference was observed when comparing $\mathrm{G}$ carriers and homozygous AA carriers in the 48-hour postoperative period (fixed-effects model: $M D=-0.05$, $95 \% \mathrm{Cl}=-0.15,0.05, P=0.31$; Fig. 2B).

Meta-analysis of $\mathrm{A} 118 \mathrm{G}$ and opioid consumption: Opioid consumption data were available from 13 studies for the first 24-hour postoperative period (4$6,20,22,24,25,27,29-32)$ and 5 studies during the 48-hour postoperative period $(4,20,31-33)$. Two studies were excluded because the results were presented in the form of median and semi-interquartile range $(31,34)$. The study by Janicki et al (26) was excluded because it lacked data from the exact postoperative time point. Finally, the studies included 1,500 homozygous 118AA patients and 1,644 $118 \mathrm{G}$ allele carriers for the 24-hour postoperative period and 313 118AA homozygotes and $282118 \mathrm{G}$ allele carriers for the 48-hour postoperative period, with several different kinds of opioids and dosing parameters. Opioid doses were reported as total 24- or 48-hour postoperative opioid consumption.

During the first 24-hour, $118 \mathrm{G}$ allele carriers exhibited significantly more opioid consumption compared with AA homozygotes (fixed-effects model: SMD = $-0.17,95 \% \mathrm{Cl}=[-0.25,-0.10], P<0.00001$; Fig. 3A). No significant heterogeneity was found across studies $\left(\chi^{2}\right.$, $P=0.24$; Fig. 3A). However, we did not find the same 
Impact of Genetic Variation on Sensitivity to Opioid Analgesics

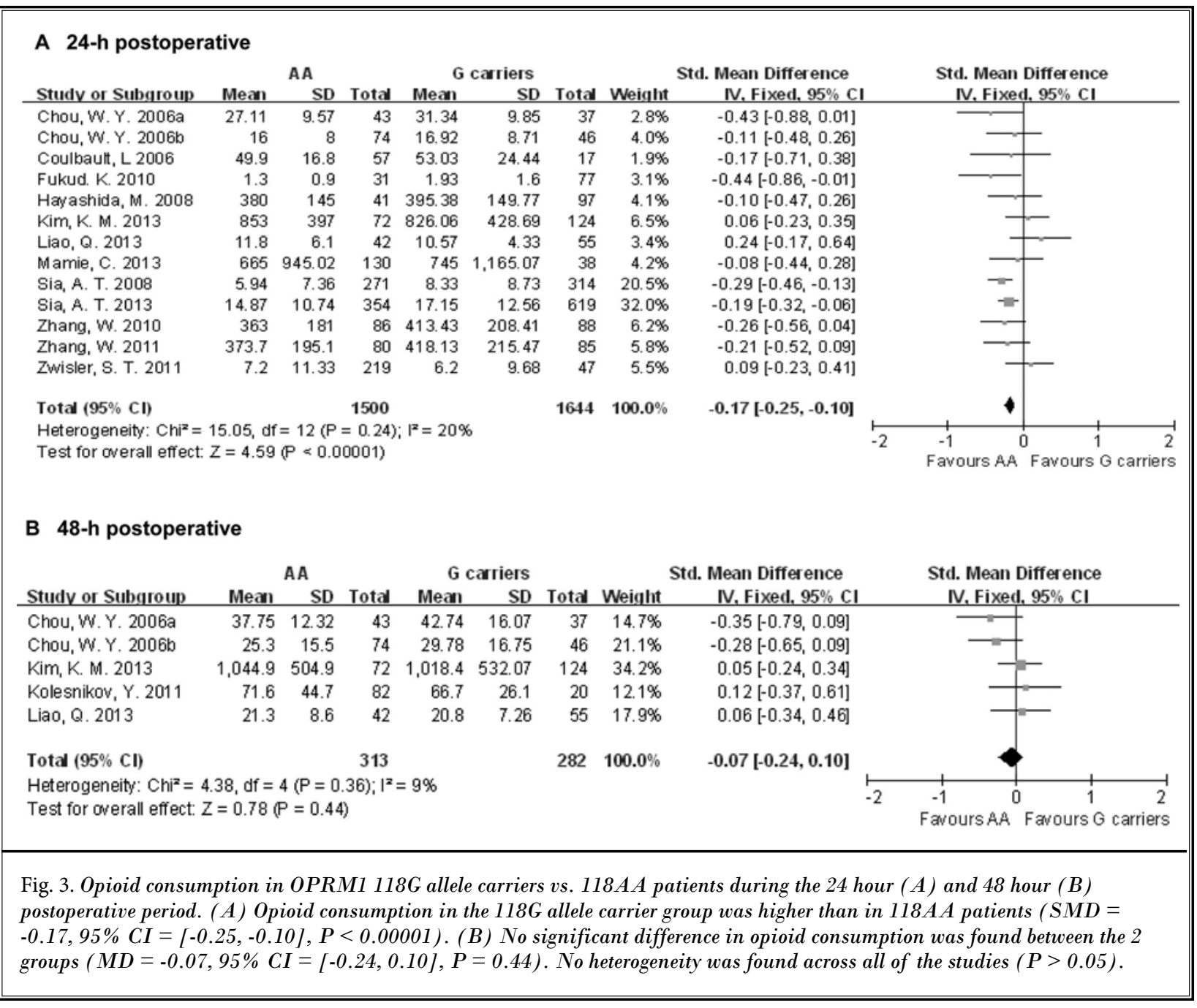

trend between AA homozygotes and G allele carriers during the 48-hour postoperative period (fixed-effects model: $\mathrm{SMD}=-0.07,95 \% \mathrm{Cl}=[-0.24,0.10], P=0.36$; Fig. 3B). No heterogeneity was found across all of the included studies ( $\chi^{2}, P=0.44$; Fig. $3 B$ ).

Meta-analysis of A118G and side effects: Data for side effects, including nausea and vomiting, were available from 11 independent studies (4-6,20,23-25,35-38). Data for nausea and vomiting were presented as 2 subgroups. Data for nausea and vomiting were pooled in the papers of Coulbault et al (5) and Zhang et al (24); they were used only once in our analysis to avoid data repetition. And the same statistical results were observed when these data were presented as either nausea or vomiting. The nausea subgroup included 851 homozygous 118AA patients and 779 118G allele carriers, whereas the vomiting subgroup included 1,140 homozygous 118AA patients and $1316118 \mathrm{G}$ allele carriers. No significant heterogeneity was observed across all of the included studies $\left(\chi^{2}, P=0.05\right.$; Fig. 4). The presence of the $118 \mathrm{G}$ allele was associated with a significantly lower rate of vomiting compared with homozygous 118AA patients (fixed-effects model: $\mathrm{OR}=1.38,95 \% \mathrm{Cl}=[1.07,1.77], P=0.01$; Fig. 4), but no significant difference was observed in the nausea subgroup (fixed-effects model: $\mathrm{OR}=1.21,95 \% \mathrm{Cl}=$ $[0.93,1.58], P=0.16$; Fig. 4). However, the overall effect was significant (fixed-effects model: $O R=1.30,95 \%$ $\mathrm{Cl}=[1.08,1.55], P=0.005 ;$ Fig. 4), indicating a lower incidence of postoperative nausea or vomiting (PNOV) among $118 \mathrm{G}$ allele carriers.

\subsubsection{Other SNPs and Postoperative Pain}

Among 3,324 SNPs in the MOR gene, many of them 
Pain Physician: March/April 2015; 18:131-152

\begin{tabular}{|c|c|c|c|c|c|c|c|c|c|c|}
\hline \multirow{2}{*}{$\begin{array}{l}\text { Studv or Subqroup } \\
3.1 .1 \text { nausea }\end{array}$} & $\begin{array}{r}\text { AA } \\
\text { Events }\end{array}$ & Total & \multicolumn{2}{|c|}{ G carriers } & Weight & $\begin{array}{l}\text { Odds Ratio } \\
\text { M-H.Fixed. } 95 \% \mathrm{Cl}\end{array}$ & \multicolumn{3}{|c|}{$\begin{array}{l}\text { Odds Ratio } \\
\text { M.H. Fixed, } 95 \% \mathrm{Cl}\end{array}$} & \\
\hline & & & & & & & & & & \\
\hline Boswell, M. V. 2013 & 27 & 131 & 6 & 27 & $3.8 \%$ & $0.91[0.33,2.47]$ & & & 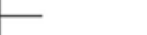 & \\
\hline Chen, L. K. 2013 & 34 & 56 & 47 & 73 & $7.8 \%$ & $0.85[0.42,1.75]$ & & & - & \\
\hline Chou, W. Y. 2006b & 6 & 74 & 1 & 46 & $0.6 \%$ & $3.97[0.46,34.10]$ & & & & \\
\hline Coulbault, L 2006 & 17 & 57 & 6 & 17 & 3. $2 \%$ & $0.78[0.25,2.45]$ & & & - & \\
\hline Liao, Q. 2013 & 14 & 42 & 23 & 55 & $6.5 \%$ & $0.70[0.30,1.60]$ & & & - & \\
\hline Sia, A. T. 2008 & 26 & 271 & 14 & 314 & $5.7 \%$ & $2.27[1.16,4.45]$ & & & & \\
\hline Zhang, F. 2013 & 16 & 54 & 31 & 74 & $9.0 \%$ & $0.58[0.28,1.23]$ & & & 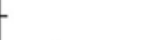 & \\
\hline Zhang, W. 2010 & 28 & 86 & 20 & 88 & $6.5 \%$ & $1.64[0.84,3.22]$ & & & $=$ & \\
\hline Zhang, W. 2011 & 28 & 80 & 19 & 85 & $5.8 \%$ & $1.87[0.94,3.72]$ & & & 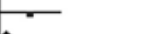 & \\
\hline Subtotal $(95 \% \mathrm{CI})$ & & 851 & & 779 & $48.8 \%$ & $1.21[0.93,1.58]$ & & & 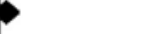 & \\
\hline Total events & 196 & & 167 & & & & & & & \\
\hline \multicolumn{7}{|c|}{$\begin{array}{l}\text { Heterogeneity: } \mathrm{Ch}^{2}=14.04, \mathrm{df}=8(P=0.08) ;\left.\right|^{2}=43 \% \\
\text { Test for overall effect: } Z=1.41(P=0.16)\end{array}$} & & & & \\
\hline \multicolumn{11}{|l|}{ 3.1.2 vomiting } \\
\hline Boswell, M. V. 2013 & 5 & 131 & 2 & 27 & $1.6 \%$ & $0.50[0.09,2.70]$ & & & 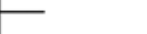 & \\
\hline Chen, L. K. 2013 & 24 & 56 & 34 & 73 & $8.2 \%$ & $0.86[0.43,1.73]$ & & & - & \\
\hline Chou, W. Y. 2006a & 7 & 43 & 5 & 37 & 2. $2 \%$ & $1.24[0.36,4.31]$ & & & & \\
\hline Chou, W. Y. 2006b & 17 & 74 & 5 & 46 & $2.3 \%$ & $2.45[0.83,7.16]$ & & & & \\
\hline Coulbault, L 2006 & 17 & 57 & 6 & 17 & $0.0 \%$ & $0.78[0.25,2.45]$ & & & & \\
\hline Liao, Q. 2013 & 8 & 42 & 10 & 55 & $3.4 \%$ & $1.06[0.38,2.97]$ & & & & \\
\hline Sia, A. T. 2008 & 10 & 271 & 11 & 314 & $4.8 \%$ & $1.06[0.44,2.52]$ & & & & \\
\hline Tan, E. C. 2009 & 65 & 389 & 58 & 605 & $18.4 \%$ & $1.89[1.29,2.77]$ & & & $\rightarrow$ & \\
\hline Zhang, F. 2013 & 8 & 54 & 19 & 74 & $6.6 \%$ & $0.50[0.20,1.26]$ & & & & \\
\hline Zhang, W. 2010 & 28 & 86 & 20 & 88 & $0.0 \%$ & $1.64[0.84,3.22]$ & & & & \\
\hline Zhang. W. 2011 & 17 & 80 & 10 & 85 & $3.7 \%$ & $2.02[0.87,4.73]$ & & & & \\
\hline Subtotal $(95 \% \mathrm{Cl})$ & & 1140 & & 1316 & $51.2 \%$ & $1.38[1.07,1.77]$ & & & $\bullet$ & \\
\hline Total events & 161 & & 154 & & & & & & & \\
\hline \multicolumn{11}{|c|}{$\begin{array}{l}\text { Heterogeneity: } \mathrm{Chi}^{2}=12.98, \mathrm{df}=8(\mathrm{P}=0.11) ; \mathrm{I}^{2}=38 \% \\
\text { Test for overall effect: } Z=2.52(P=0.01)\end{array}$} \\
\hline Total $(95 \% \mathrm{CI})$ & & 1991 & & 2095 & $100.0 \%$ & $1.30[1.08,1.55]$ & & & $\bullet$ & \\
\hline \multirow{2}{*}{\multicolumn{7}{|c|}{$\begin{array}{l}\text { Heterogeneity: } \text { Chi }^{2}=27.60, d f=17(P=0.05) ; I^{2}=38 \% \\
\text { Test for overall effect: } Z=2.80(P=0.005)\end{array}$}} & & & & \\
\hline & & & & & & & 0.01 & 1 & 10 & $100^{\circ}$ \\
\hline
\end{tabular}

Fig. 4. Decreased risk of side effects, including nausea and vomiting, in OPRM1 118G allele carriers vs. 118 AA patients (OR = $1.30,95 \% C I=[1.08,1.55], P=0.005$, for overall effects). The rates of vomiting were lower in the $118 G$ allele carrier group than in 118 A A patients $(O R=1.38,95 \% \mathrm{CI}=[1.07,1.77], P=0.01)$, but the rates of nausea were not significantly different between the 2 groups $(O R=1.21,95 \% C I=[0.93,1.58], P=0.16)$. No heterogeneity was found across all of the studies $(P>0.05)$.

have extremely low frequencies, making exploration of the association with pain difficult at the population level (39). However, the minor allele frequencies of 1,395 genetic variants are greater than $1 \%$ in the global population (39). Besides SNPs, there are 4 substantial linkage disequilibrium (LD) blocks in the MOR gene (40). A118G, IVS2+G691C (rs2075572), IVS3+G5953A (rs599548), IVS3+A8449G (rs9384179), and TAA+A2109G (rs558025) are 5 tag SNPs that represent the 4 LD blocks of the OPRM1 gene. The IVS2+G691C SNP in intron 2, representing the second LD block, has been studied with regard to nicotine dependence (41), acute drug dose (42), and heroin addiction (43). The frequency of the minor allele varies from $54.5 \%$ to $81.9 \%$ in differ- ent ethnic populations (44). Hayashida et al (31) investigated the influence of IVS2+G691C on clinical pain management and found that the IVS2+G691C variant had no impact on postoperative opioid consumption. Fukuda et al (33) examined associations between fentanyl sensitivity and IVS3+A8449G, which is located in intron 3 and represents a complete LD block with more than 30 SNPs from intron 3 to the 30 untranslated region. They found that individuals who carry the $G$ allele consumed less fentanyl compared with patients without the $\mathrm{G}$ allele during the 24-hour postoperative period, but no statistically significant difference in pain scores was found between the 2 groups. These results are inconsistent with Hayashida et al (31), who did 
not report a relationship between IVS3+A8449G and postoperative opioid requirements. Another 2 SNPs, IVS3+G5953A in intron 3 and TAA+A2109G, representing the fourth LD block, also did not influence postoperative pain management (31). T172G (rs6912029) in exon 1 is a promoter SNP and has been studied in methadone maintenance patients $(46,47)$ and opiatedependent individuals (48). In a relatively large sample that consisted of different ethnicities, Tan and coworkers (38) concluded that the T172G variant had no impact on postoperative pain management, including pain score, opioid consumption, and adverse effects. A paper published by Ochroch et al (49) investigated the relationship between 20 SNPs in the MOR gene and postoperative pain scores 3 days after thoracotomy, indicating that 4 SNPs (i.e., rs634479, rs499796, rs548646, and rs679987) were associated with postoperative pain, and 5 SNPs (i.e., rs9322447, rs606148, rs599945, rs613341, and rs616585) approached statistical significance, but these results require further confirmation in a relatively larger sample.

\subsection{Cytochrome P450 System}

Cytochrome P450 (CYP450) comprises a series of enzyme families, including 57 putatively functional human enzymes (50), and plays an important role in catalyzing the oxidative biotransformation of most drugs, including opiates $(51,52)$. Most enzymes of CYP450 are expressed mainly in the liver and consist of 3 families (i.e., CYP1, CYP2, and CYP3). The CYP1 family has 2 subfamilies: CYP1A and CYP1B. CYP1A-related genes (CYP1A1 and CYP1A2) are located on chromosome 15q24.1, which contains 7 exons and 6 introns (53). The CYP1B subfamily has only one type (CYP1B1), which is located on chromosome 2p22.2 (47). The CYP2 family consists of 4 subfamilies: CYP2A, CYP2B, CYP2C, and CYP2D. The CYP2A subfamily mainly includes CYP2A6, CYP2A7, and CYP2A13, which are located on chromosome $19 q 13.2$ (48). The CYP2B subfamily has only one functional CYP2B6 gene located on chromosome 19 (54). CYP2B6 can be induced and activated during pregnancy, resulting in an increased incidence of methadone clearance (54). The CYP2D gene is located on chromosome 22q13.1. CYP2D has one functional gene (CYP2D6) and 2 pseudogenes (CYP2D7 and CYP2D8) (55). Codeine is metabolized by CYP2D6 to the active morphine metabolite, which has 3000 -fold greater affinity for the MOR than codeine (56-58). The CYP3 enzyme has only one subfamily (CYP3A), which is located on chromosome 7q22.1. The impact of CYP3A on opiate metabolism has been investigated mainly with regard to fentanyl $(50,51,59)$ and oxycodone $(45,52,60)$. Concerning the crucial role of the CYP450 family in opiate metabolism, we tested the association between these genetic variants and postoperative pain.

\subsubsection{CYP2D6 and Postoperative Pain}

CYP2D6 is a unique functional protein in the CYP2D subfamily. To date, more than 100 allelic variants of CYP2D6 have been identified (www.cypalleles.ki.se/). Because of genetic polymorphisms, the products can be divided into 4 phenotypes: poor metabolizer (PM), intermediate metabolizer (IM), extensive metabolizer (EM), and ultrarapid metabolizer (UM). Distinct CYP2D6 variants play differential roles in opiate metabolism. Persson et al reported that most EM patients had satisfactory analgesia when using codeine after hysterectomy, with the exception of one patient who had severe hip damage (47). VanderVaart and co-workers suggested that codeine had no effect on analgesia in PM patients, whereas UM patients achieve immediate pain relief but have severe side effects (48). Tramadol is a synthetic opioid with a lower incidence of morphinelike effects (63), such as abuse potential (64) and the depression of respiration (32). It is metabolized by CYP450 to 11 desmethylated compounds, of which O-desmethyltramadol predominates and possesses analgesic properties $(44,56)$. O-desmethyltramadol and the MOR have strong affinity, which is 200 -fold greater than tramadol (65). PM patients require more tramadol than EM patients and have a lower response rate to tramadol compared with EM patients (66). This is inconsistent with another study that found that tramadol consumption, side effects, and pain scores at specific postoperative time points were not significantly different between CYP2D6 genotypes (67). Wang et al (68) focused on the relationship between tramadol and the CYP2D6*10 C188T polymorphism, which is the most common allele, with a frequency that ranges from $51 \%$ to $70 \%$ in the Chinese population, indicating that heterozygous CYP2D6*10 carriers require less tramadol than homozygotes. Morphine is a traditionally used analgesic, and morphine requirements vary widely among individuals. UM patients consumed less morphine and had lower pain scores than other phenotypes in the acute postoperative period (52). CYP2D6 catalyzes oxycodone to form oxymorphone (53), which has a 10- to 40-times higher affinity than the prototype (69). However, no significant difference was found in oxycodone consumption between PM and EM patients during the 
acute postoperative period (53). Additionally, Wesmiller et al (70) found that the CYP2D6 genotype influenced the occurrence of postoperative nausea and vomiting, and PM patients had a lower rate of occurrence of nausea and vomiting and higher pain score. In summary, gene variants of CYP2D6 contribute to individual postoperative pain management.

\subsubsection{CYP3A4 and Postoperative Pain}

Among the CYP3A subfamily, the most studied variant was CYP3A4. The CYP3A4 gene has approximately 40 alleles (www.cypalleles.ki.se/). Variations in CYP3A4 result in changes in enzyme activity, and $30-$ $85 \%$ of the interindividual variability in CYP3A4 activity depends on genetic factors $(71,72)$. Numerous studies have explored the relationship between pain management and CYP3A4 $(21,32,61-64,73)$, all of which were conducted in the Asian population.

CYP3A4*1G and postoperative pain: CYP3A4*1G (20230G >A) has a G-to-A substitution in intron 10 (64). It is a high-frequency allele in Asians (0.249 in Japanese [32] and 0.221 in Chinese [64]). Several studies $(63,73-75)$ have discussed the relationship between CYP3A4*1G and pain management in the Chinese population. The CYP3A4*1G variant allele leads to decrease in enzyme activity $(76,77)$. During the first 24 -hour postoperative period, fentanyl consumption was lower in the $* 1 \mathrm{G} /{ }^{*} 1 \mathrm{G}$ genotype compared with the $* 1 / * 1$ and $* 1 / * 1 \mathrm{G}$ genotypes $(32,78)$, and the plasma concentration of fentanyl was higher in the $* 1 \mathrm{G} /{ }^{*} 1 \mathrm{G}$ group (61). These results were inconsistent with the findings reported by Dong et al (63), in which no significant difference in fentanyl consumption was observed in the 24 and 48-hour postoperative periods. Similarly, pain scores and adverse effects were not significantly different among the 3 genotypes $(61,63,73)$.

Meta-analysis of CYP3A4*1G and pain scores: Available data were retrieved from 2 independent studies $(61,73)$. One study was excluded because the data were presented in the form of median and semi-interquartile range (63). The final meta-analysis included 178 homozygous $* 1 / * 1$ and $141 * 1 \mathrm{G}$ carriers. No heterogeneity was detected in either the 0 hour group $\left(\chi^{2}, P=0.81\right.$; Fig. 5A) or 24-hour group $\left(\chi^{2}, P=0.38\right.$; Fig. $\left.5 \mathrm{~B}\right)$. The results of the meta-analysis revealed that pain scores were not significantly different between $* 1 / * 1$ homozygotes and $* 1 \mathrm{G}$ carriers at 0 hour (fixed-effects model: $\mathrm{MD}=0.06,95 \% \mathrm{Cl}$ $=[-0.22,0.33], P=0.67$; Fig. $5 \mathrm{~A}$ ) or 24-hour (fixed-effects model: $\mathrm{MD}=0.04,95 \% \mathrm{Cl}=[-0.15,0.23], P=0.66$; Fig. 5B).

Meta-analysis of CYP3A4*1G and fentanyl con- sumption: The same studies were included as mentioned above. Similarly, 178 homozygous *1/*1 and $141 * 1 \mathrm{G}$ carriers were included in this meta-analysis. One study was excluded because the results were presented in the form of median and semi-interquartile range (63). Individuals who carried the * $1 \mathrm{G}$ allele required less fentanyl during the first 24-hour postoperative period than individuals with the wildtype $* 1 / * 1$ genotype (fixed-effects model: $\mathrm{MD}=45.12,95 \% \mathrm{Cl}=[36.17,54.06], P<0.00001$; Fig. $5 C)$, with no heterogeneity detected $\left(\chi^{2}, P=0.56\right.$; Fig. 5C).

Meta-analysis of CYP3A4*1G and side effects: Side effects mainly include PONV. The data were derived from 2 studies $(61,73)$. Among 178 homozygous * $1 / * 1$ carriers, 54 reported PONV, whereas among $141 * 1 \mathrm{G}$ carriers, 37 reported PONV. No significant difference was found in the incidence of PONV between the $* 1 \mathrm{G} / * 1 \mathrm{G}$ and $* 1 / * 1 \mathrm{G}$ groups (fixed-effects model: $\mathrm{OR}=$ $1.23,95 \% \mathrm{Cl}=[0.75,2.01], P=0.42$; Fig. 5D). No heterogeneity was detected ( $\chi^{2}, P=0.62$; Fig. 5D).

Other variants of CYP3A4 and postoperative pain: Other variants of CYP3A4 include CYP3A4*18 and CYP3A4*18B. CYP3A4*18 is a promoter SNP and has been extensively studied because of its role in transcriptional regulation in vitro (79). Tan et al (64) suggested that CYP3A4*18 had no effect on postoperative fentan$\mathrm{yl}$ consumption in the Malaysian Malay population. This is consistent with findings in Koreans by Kim et al (32), in which the CYP3A4 genetic polymorphism had no relationship with postoperative fentanyl dose. Additionally, pain scores and adverse effects were not influenced by CYP3A4*18 (64). This phenomenon requires further confirmation in a larger sample. A recent study investigated the effect of CYP3A4*18B on postoperative pain in the Chinese population (21). CYP3A4*18B, which has a high frequency in Asians, has a G-to-A substitution in intron 10 and is correlated with increased enzyme activity $(74,75)$. One study by Liao et al $(21)$ indicated that CYP3A4*18B had no effect on postoperative pain score and untoward effects. They found no significant difference in fentanyl requirements among 3 genotypes during the 24-hour postoperative period, whereas the * $18 \mathrm{~B}$ allele was associated with less fentanyl consumption at 48 hours (21).

\subsubsection{CYP3A5 and Postoperative Pain}

The expression of CYP3A5 in the liver differs among ethnicities (76). The variants of CYP3A5 can influence protein expression and enzyme activity. CYP3A5*3 is the most common variant that induces a mutation in 
Impact of Genetic Variation on Sensitivity to Opioid Analgesics

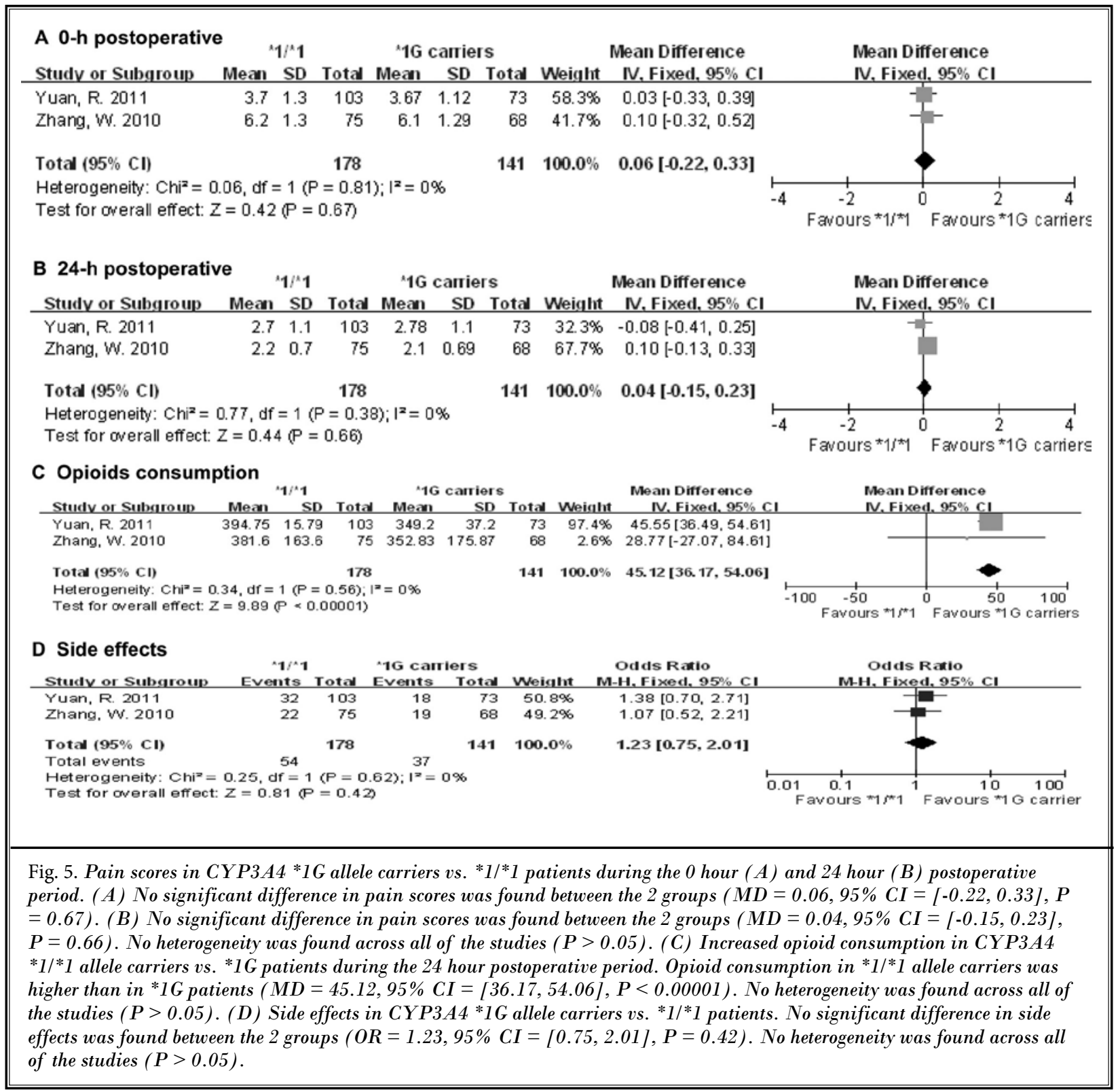

intron 3, resulting in aberrant splicing and truncation (76). CYP3A5*3 presents a high frequency in Asians $(32,77,78)$. Fentanyl consumption was not significantly correlated with CYP3A5*3 in Chinese and Koreans $(32,62)$, but a trend toward an association between decreased fentanyl consumption and CYP3A $5 * 1 / * 3$ and CYP3A $5 * 3 / * 3$ polymorphisms was detected in Chinese (62). When combined with CYP3A4*1G, CYP3A5*1/*3 and $C Y P 3 A 5 * 3 / 3$ genotypes presented significantly lower fentanyl requirements than wildtypes (62). These results suggest an interaction among CYP450 genes.
Meta-analysis of CYP3A5*3 and opioid consumption: Data were obtained from 2 studies $(32,62)$ that included 26 homozygous $* 1 / * 1$ and $373 * 3$ carriers. No heterogeneity was detected across studies $\left(\chi^{2}, P=\right.$ 0.65; Fig. 6). When the data were pooled, wildtype and mutation carriers presented no significant difference in fentanyl consumption (fixed-effects model: $M D=33.81$, $95 \% \mathrm{Cl}=[-68.58,136.20], P=0.52 ;$ Fig. 6$)$.

\subsection{P-glycoprotein}

P-glycoprotein (P-gp) is encoded by the adenosine 


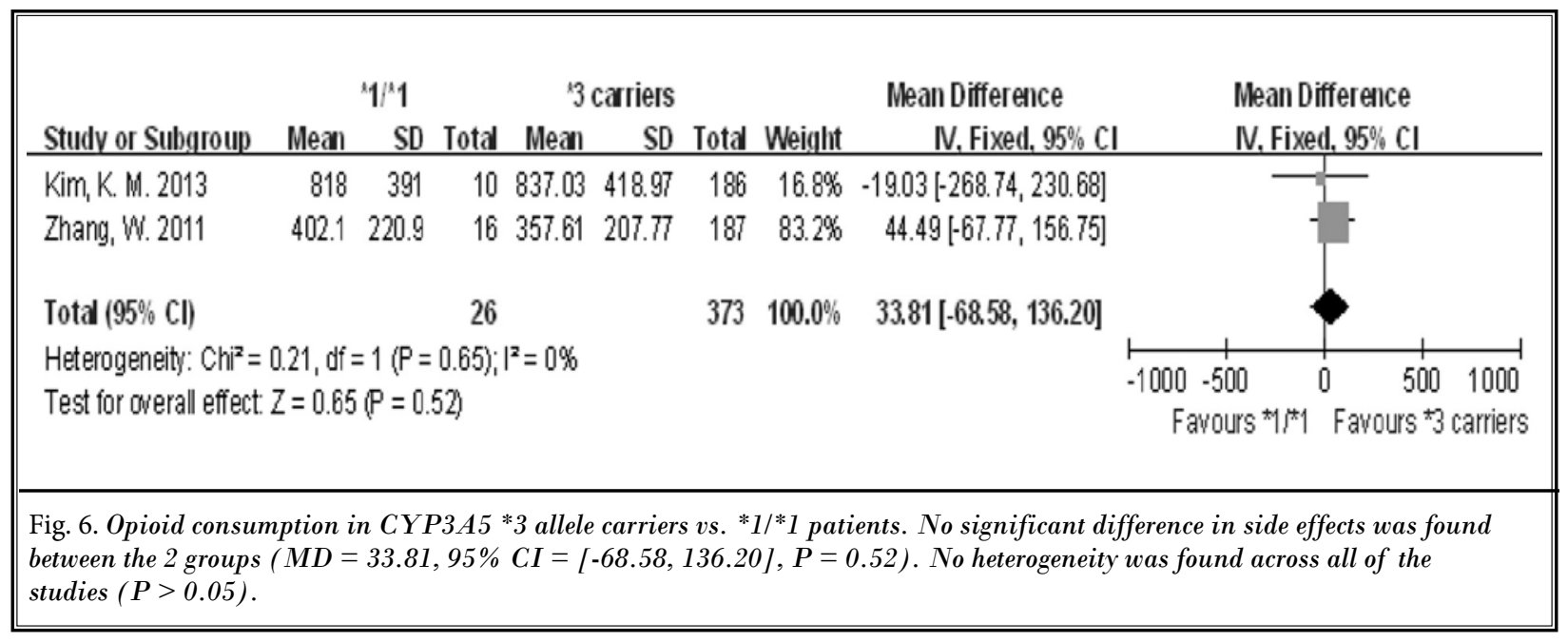

triphosphate (ATP)-binding cassette subfamily B member-1 ( $A B C B 1$ ) gene. It is a transporter for drug efflux (80) that is expressed in biological barriers, including the blood-brain barrier (BBB) and intestinal wall (81). $\mathrm{P}$-gp is considered the major constituent of the BBB that can restrict the disposition of certain opioids in the brain (80). A number of opioids, including morphine and fentanyl, are all substrates of P-gp (82). Therefore, $A B C B 1$ is highly associated with the function of P-gp, and any mutation in this gene could lead to abnormal opioid-induced analgesia.

$A B C B 1$ and pain: The SNP of $A B C B 1$ can influence the expression and activity of P-gp. C3435T and G2677T are the most extensively investigated SNPs that have minor allele frequencies in the European population (approximately $50 \%$ and $42-45 \%$, respectively) $(83,84)$. The P-gp expression level was affected by distinct genotypes and led to different analgesic effects. Many studies have suggested that C3435T is associated with opioid consumption in the management of either acute or chronic pain $(18,85)$. However, Sia et al (86) found that the ABCB1 C3435T SNP is irrelevant for opioid consumption, but they found that homozygous TT patients had a higher risk of persistent pain than wildtype CC patients. Kim et al suggested that $A B C B 12677 G>T / A$ and $3435 C>T$ were not related to variability of the analgesic response to fentanyl (32). In another study, no significant difference was found in opioid dose requirements between distinct variants (5).

Meta-analysis of ABCB1 C3435T and opioid consumption: Opioid consumption data were available from 7 studies $(5,27,32,51,86-88)$. One study was excluded for a lack of available data for specific post- operative periods (89). The studies finally included 456 homozygous CC patients and 1,176 T allele carriers. No heterogeneity was detected across studies $\left(\chi^{2}, P=0.48\right.$; Fig. 7A). When the data were pooled, wildtype and mutation carriers did not exhibit significant differences in opioid consumption (fixed-effects model: $S M D=-0.01$, $95 \% \mathrm{Cl}=[-0.12,0.10], P=0.82 ;$ Fig. 7A).

Meta-analysis of ABCB1 G2477T/A and opioid consumption: Opioid consumption data were available from 4 studies $(5,27,32,86)$. One study was excluded for a lack of available data for specific postoperative periods (89). One study was excluded because the results were presented in the form of median and semi-interquartile range (90). The studies finally included 286 homozygous GG patients and 862 other allele carriers. No heterogeneity was detected across studies $\left(\chi^{2}, P=0.66\right.$; Fig. 7B). When the data were pooled, homozygous GG patients and other mutation carriers did not exhibit significant differences in opioid consumption (fixed-effects model: $\mathrm{SMD}=-0.01,95 \% \mathrm{Cl}=[-0.15,0.13], P=0.88 ;$ Fig. $7 \mathrm{~B})$.

\subsection{Catechol-0-methyltransferase}

The catechol-O-methyltransferase (COMT) gene is located on chromosome 22 (22q11.1-q11.2), including 6 exons (91). A functional G-to-A transition that results in a Val-to-Met amino-acid substitution has been implicated in the regulation of pain (92). The COMT enzyme can metabolize catecholamines (e.g., dopamine, epinephrine, and norepinephrine) of glial cells and postsynaptic neurons in the central nervous system and other tissues (93). Previous studies showed that lower COMT activity results in an increase in pain sensitivity in both animals and humans $(94,95)$.

Catechol-O-methyltransferase Val158Met and pain: 
The most common SNP of COMT is COMT G1947A, also called COMT Val158Met. The methionine at codon 158 reduces enzyme thermostability. Homozygous 1947AA carriers exhibit a 3- to 4-fold reduction of enzyme activity than $\mathrm{G}$ allele carriers, resulting in a decrease in the degradation of catecholamines in individuals with the A allele (96) and have increased pain sensitivity (97). Osteoarthritis patients with the Val158Met variant exhibited higher pain levels (98), and lower COMT enzyme activity leads to an increase in pain sensitivity when exposed to mechanical or thermal stimulation (99). Reyes-Gibby et al (17) investigated the combined effect of the COMT Val158Met variant and OPRM1 A118G polymorphism. The results indicated that patients with the 118AA and Met/Met genotype consumed less opioids to relieve pain than any of the other genotypes tested (17).

\subsection{Serotonergic System}

Serotonin receptors: Serotonin is among the most important analgesic substances for modulating the pain response. Increased serotonin levels can act on postsynaptic receptors, activate serotonin receptors and downstream signaling pathways, and result in the generation of pain.

\subsubsection{Serotonin-1A Receptor and Pain}

The 5-HT1A gene (HTR1A) is located on chromosome 5q11.2-13. It spans approximately 1200 bp without introns. Fifty important SNPs are known to date, and most of them are in almost complete linkage disequilibrium (LD). Among all of the SNPs, -1019C/G (rs6295), which determines the transcription rate of the HTR1A gene, has been shown to significantly affect serotonergic neurotransmission (100-102). Allele

\section{A ABCB1 C3435T}

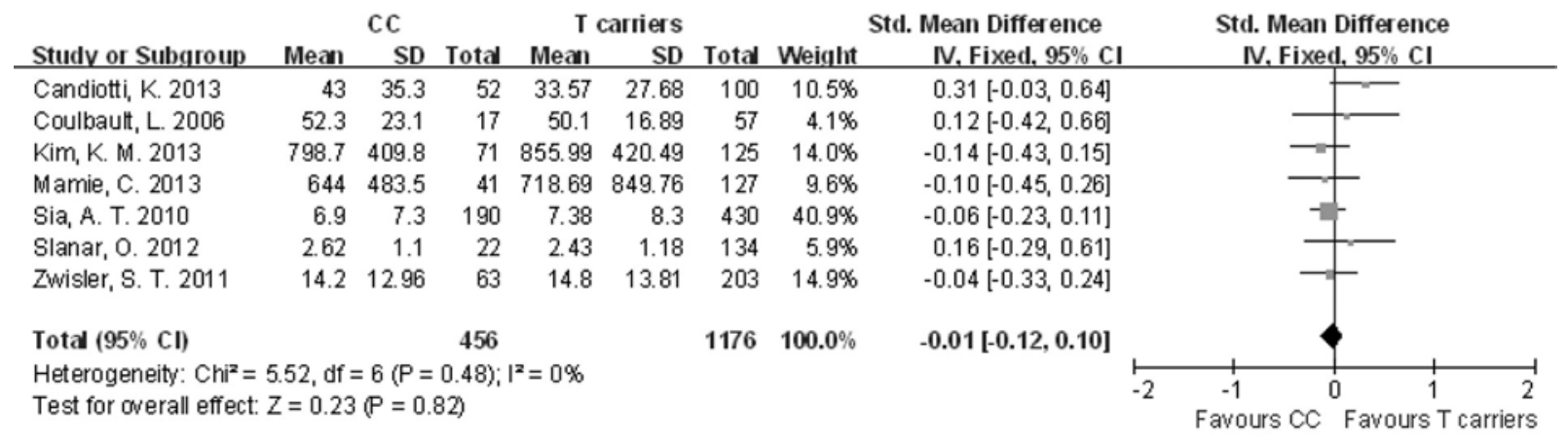

\section{B ABCB1 G2477T/A}

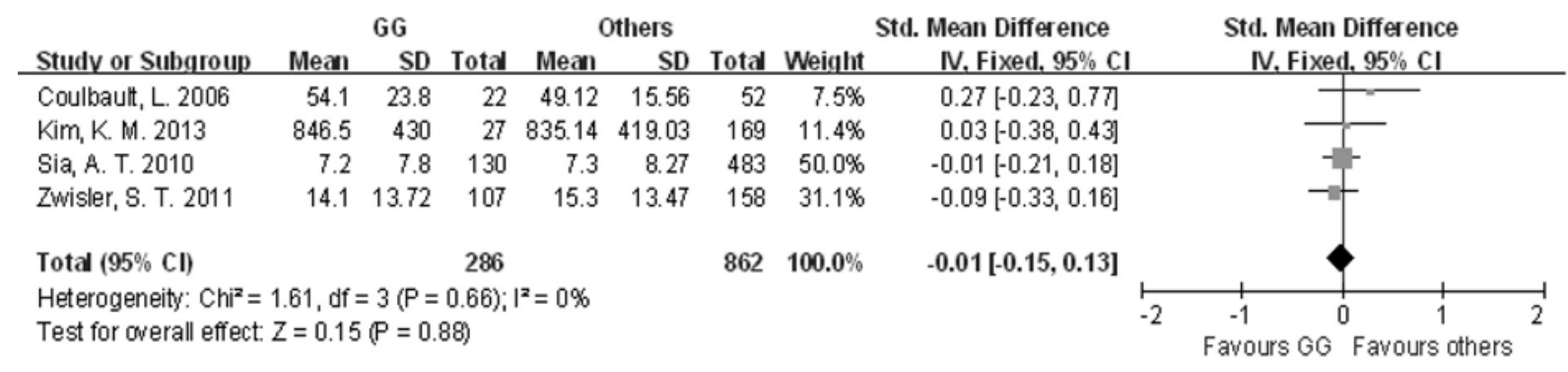

Fig. 7. Opioid consumption in (A) ABCB1 $3435 T$ allele carriers vs. $C / C$ patients and (B) ABCB1 G/G carriers vs. other variants. In (A), no significant difference in side effects was found between the 2 groups (SMD $=-0.01,95 \% C I=[-0.12$, $0.10], P=0.82)$. No heterogeneity was found across all of the studies $(P>0.05)$. In $(B)$, no significant difference in side effects was found between the 2 groups $(S M D=-0.01,95 \% C I=[-0.15,0.13], P=0.88)$. No heterogeneity was found across all of the studies $(P>0.05)$. 
frequency distributions are significantly different between Caucasians and Asians. The $\mathrm{G}$ allele has been identified in approximately $50 \%$ of Caucasians but only $21 \%$ of Asians $(103,104)$. 5-HT1AR agonists has been investigated for their therapeutic potential in pain relief (105). Repeated morphine administration leads to tolerance and even hyperalgesia, but repeated administration of a 5-HT1AR agonist can reverse this effect by inducing the loss of hyperalgesia and increasing analgesia (106).

\subsubsection{Serotonin-2A Receptor and Pain}

The $5-\mathrm{HT}_{2 \mathrm{~A}}$ receptor gene is mapped on chromosome 13q14-21 and consists of 3 exons that span over $60 \mathrm{~kb}$. The promoter region has 2 important SNPs (-1438A/G [rs6311] and -102T/C [rs6313]) that show strong LD $(107,108)$. The $-1438 G(102 \mathrm{C})$ allele was reported to be present in almost $50 \%$ of different populations, including Caucasians and Asians (109). Abbott et al (110) reported that treatment with $5-\mathrm{HT}_{2 \mathrm{~A}} / 2 \mathrm{C}$ antagonists and a $5-\mathrm{HT}_{2 \mathrm{~A}}$ antagonist decreased the pain response. Tokunaga et al (111) also reported that the pain response was attenuated by treatment with a $5-\mathrm{HT}_{2 \mathrm{~A}}$ receptor antagonist. $5-\mathrm{HT}_{2 \mathrm{~A}}$ receptor activation has been implicated in the process of pain modulation. Previous studies suggested that patients with irritable bowel syndrome (IBS) or fibromyalgia and the T/T genotype exhibited higher pain sensitivity than patients with other genotypes (112-114).

Aoki et al (115) investigated the relationship between the 102T/C polymorphism and individual differences in analgesic requirements in patients with postoperative pain. They suggested that women with the $T / T$ genotype tended to have greater analgesic requirements than those with other genotypes (115).

\subsection{Ion-Channel Function}

Pain is felt through the activation of nociceptors on sensory neurons that detect high-threshold stimuli, including extremes of temperature and mechanical force or chemical exposure (e.g., acids or prostaglandins). Such signals are then transmitted to the central nervous system $(116,117)$. Ligand-gated ion channels or voltage-gated ion channels play a pivotal role in detecting and transmitting stimulus signals. Early findings indicated that ion channel variants may modulate the risk, severity, and persistence of pain after injury (118). In the present review, we discuss and highlight the role of ion channels in pain modulation.

\subsubsection{TRP Channels and Pain}

Numerous transient receptor potential (TRP) channels have been shown to be expressed on sensory neurons. Vanilloid-1 (TRPV1) was the first TRP receptor discovered and is a nonselective cation channel that is activated by noxious stimuli, leading to pain mediated by discharges in C-polymodal and $\mathrm{A} \delta$ mechanoheat nociceptors $(119,120)$. In animals, genetic variability in TRPV1 has been reported to be associated with an increase in surgical pain (121-123). Recently, Ochroch and colleagues (49) examined the association between distinct genetic variants and pain in 90 patients on postoperative day 3 , but no significant difference was detected between TRPV1 and postoperative pain.

\subsubsection{Voltage-gated Sodium Channels and Pain}

Voltage-gated sodium channels (Nav) are crucial in the process of nociceptor excitability and signal transmission. Diverse channels (e.g., Nav1.7, Nav1.8, and Nav1.9) are preferentially expressed in peripheral neurons and execute distinct functions related to the regulation of pain (124-126). Before the congenital insensitivity to pain phenotype was discovered in 2006, people did not realize the importance of mutations in the SCN9A gene $(127,128)$. SCN9A encodes the Nav1.7 voltage-gated sodium channel and is mainly expressed in dorsal root ganglion neurons and sympathetic ganglion neurons (129). Many studies have identified mutations in SCN9A that contribute to the development of pain disorders, ranging from abnormal pain sensitivity to the partial loss of pain perception (127-131). The 3312G>T SNP that is located within exon 16 of the SCN9A gene leads to an amino acid substitution and is associated with the incidence of congenital insensitivity to pain (132). Duan et al (133) explored the role of $3312 \mathrm{G}>\mathrm{T}$ in the SCN9A gene in predicting individual baseline pain perception and postoperative pain sensitivity in the general population. The results suggested that patients who carry the SCN9A 3312T allele have lower postoperative pain sensitivity and a decreased likelihood of developing inadequate analgesia than those who carry the $3312 \mathrm{G}$ allele (133).

\subsection{Publication Bias Analysis}

We applied a series of strategies to investigate possible publication biases. Fig. 8 presents funnel plots of the statistically significant meta-analysis. No publication bias was evident for OPRM1 A118G, ABCB1 C3435T, or ABCB1 2477T in the present study. However, 
because of the limited number of articles included in the final analysis, publication bias cannot be assessed for CYP3A4 and CYP3A5 gene SNPs.

\section{Discussion}

Our meta-analysis showed that OPRM1 118G allele carriers consumed more opioids for analgesia but reported higher pain scores and less nausea and vomiting than homozygous 118AA patients during the first 24hour postoperative period but not 48-hour postoperative period. CYP3A4*1G carriers consumed less opioids than homozygous CYP3A4*1/*1 patients. Our results indicate that $118 \mathrm{G}$ allele carriers have lower sensitivity to opioid analgesics, including both opioid-induced analgesic effects and side effects, together with less satisfactory pain management than 118AA homozygotes. In terms of CYP3A4, *1G carriers had higher sensitivity to opioid-induced analgesia compared with *1/*1 homozygotes.

With emerging evidence of the clinical relevance (15) and therapeutic predictive value (18) of OPRM1 SNPs, the inclusion of the OPRM1 118A>G variant in personalized therapeutic concepts for pain has been increasingly contemplated. A meta-analysis targeted the OPRM1 118A>G variant and its effects on opioids, but no significant association was found (19). This was opposite to our results. One important reason may be the heterogeneity across datasets and population stratification in the study by Walter and Lotsch (19) that mixed cancer pain, non-cancer pain, and postoperative pain, whereas our meta-analysis included only postoperative pain. It could be more difficult to derive gene-opioid effect relationships from data of patients with different types of pain, for the mechanism, severity, and nature differ substantially. Secondly, in cancer patients, pain is much more severe and persistent. Pain sensitivity varies after long-term opioid analgesic medication, which can also produce abnormal pain perception, either hyperalgesia or hypoalgesia (134-136). Additionally, pain assessment at different time points, such as incident pain, end-of-dose failure pain, uncontrolled persistent pain, and well-managed cancer pain, substantially affect pain ratings (137). As a result, pain and opioids consumption in cancer pain patients may not be comparable to that in postoperative patients. Song et al (138) conducted a meta-analysis of the association between the OPRM1 A118G polymorphism and epidural analgesia with fentanyl during labor. Contrary to the aforementioned meta-analysis results, this study reported that $118 \mathrm{G}$ carriers required less fentanyl but reported higher an- algesic satisfaction than AA homozygotes during labor. A large number of paradoxical reports in this field still exist in the literature $(3,16,19)$. A recently published meta-analysis by Hwang et al (139) supported our finding. Hwang and his colleagues found that the OPRM1 118G carriers required a higher mean opioid dose than AA homozygotes. One more interesting finding was that the subgroup analysis revealed the A118G affects the requirement for postoperative morphine but not fentanyl (139). Hwang's finding suggests that pharmacogenetic effect of A118G SNP on response to opioid agonists may be ligand dependent, which may explain the contradictory reports of Song et al (138).

Our meta-analysis showed that $118 \mathrm{G}$ allele carriers had decreased sensitivity to opioids, reflected by more opioid consumption, less nausea and vomiting, and higher pain ratings. This can be partially interpreted by related basic research findings. Results from in vitro experiments and an analysis of postmortem human brains reported lower MOR expression for the $118 \mathrm{G}$ allele compared with the $118 \mathrm{~A}$ prototypic receptor, which had a "gene dose"-dependent reduction of receptor number as the number of $118 \mathrm{G}$ alleles increased (140142). Genetic influences on pain sensitivity and pain modulation have been strongly supported by a large amount of animal literature, with highly pain-sensitive animals exhibiting less responsiveness to analgesics (143-145), indicating high pain sensitivity may both enhance pain intensity and reduce the general effectiveness of endogenous and exogenous analgesia. This was also observed in human experimental pain $(146,147)$, with a decrease in opioid-induced miosis $(148,149)$ in carriers of the MOR variant N40D. This is consistent with an interesting phenomenon, in which the alfentanil concentration-dependent analgesic effect linearly decreased with pain-related brain activation. This suggests that the increase in opioid requirements in pain patients who carry the MOR variant $\operatorname{N40D}(4,15)$ is mainly attributable to a reduction of the sensory intensity of pain.

The results for the 48-hour postoperative period were not significantly different between OPRM1 118G allele carriers and homozygous 118AA patients for several reasons, although there has presented a trend the same as the 24 hours cohort. Firstly, the smaller sample size may limit the statistical significances; secondly, for postoperative patients, pain at the 48-hour postoperative period is less terrible than that at the 24 -hour postoperative period. Therefore, many associations may not be identified. 


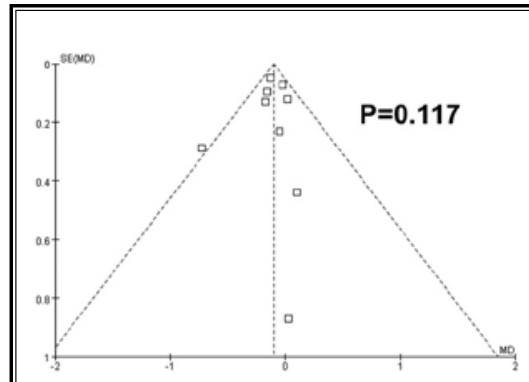

A118G and pain score during 24-h postoperative period

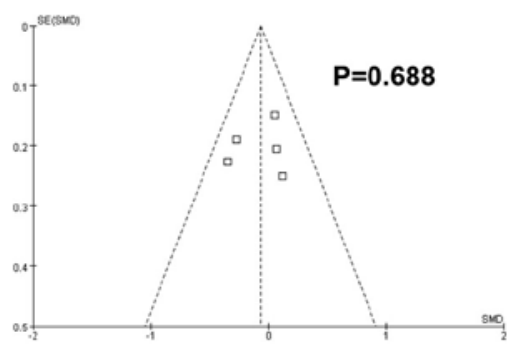

A118G and opioid consumption during 48-h postoperative period

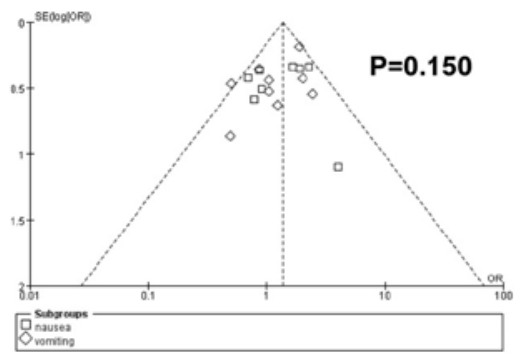

A118G and side effects

A118G and pain score during 48-h postoperative period

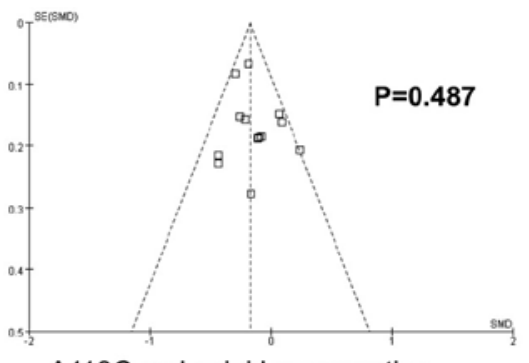

A118G and opioid consumption during 24-h postoperative period

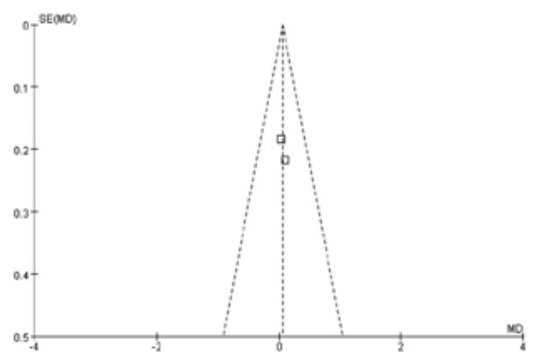

CYP3A4 and pain score during 0-h postoperative period

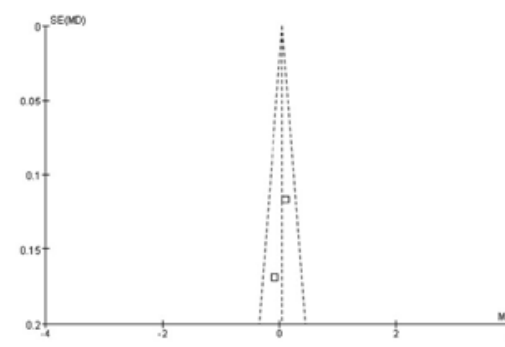

CYP3A4 and pain score during 24-h postoperative period

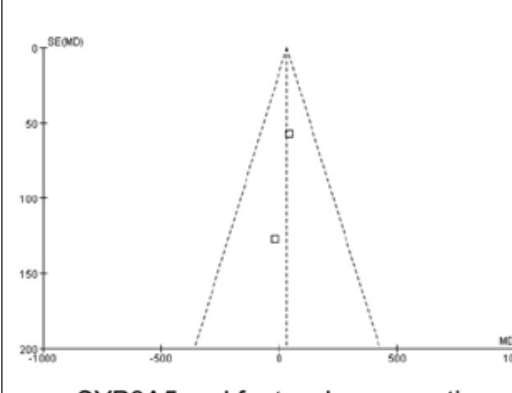

CYP3A5 and fentanyl consumption

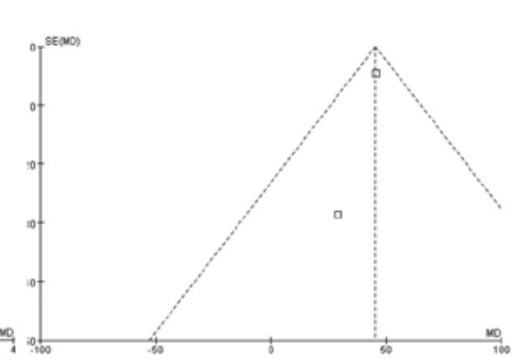

CYP3A4 and opioids consumption

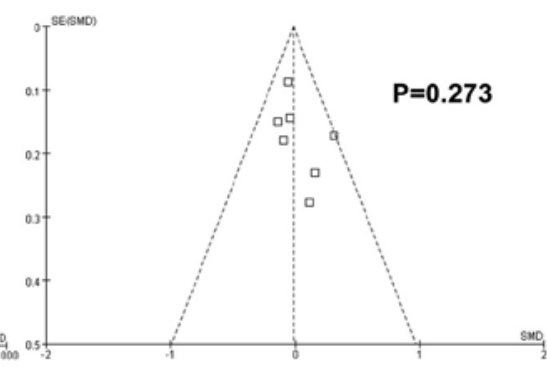

C3435T and opioids consumption

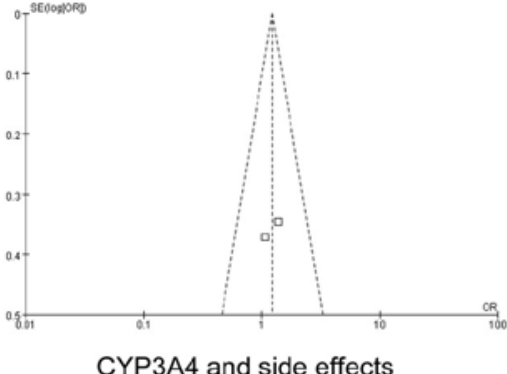

CYP3A4 and side effects

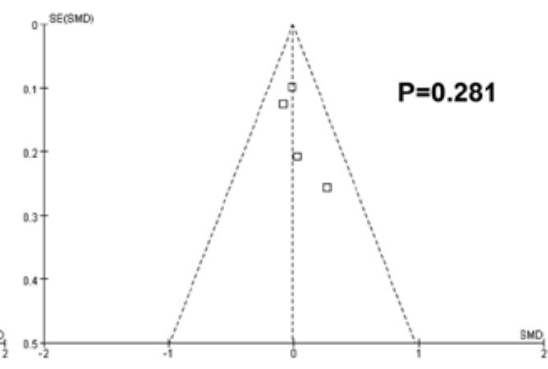

G2477T/A and opioids consumption

Fig. 8. Funnel plots of statistically significant meta-analyses. No significant publication bias was evident for OPRM1 A118G, ABCB1 C3435T, and ABCB1 $2477 T$ in the present study. 
In our meta-analysis, we found that CYP3A4 *1G carriers consumed less opioids than homozygous CYP3A4*1/*1 patients. However, to our knowledge, no meta-analysis has focused on the association between the CYP3A4 SNP and postoperative pain and opioid analgesics. Moreover, few studies published prior to January 2014 targeting the CYP3A4 SNP and pain modulation. Therefore, the results need to be further confirmed in larger samples.

The finding that the A118G SNP of OPRM 1 has the most potent influence on postoperative pain management undoubtedly provides important insight into the multiplicity of genentic factors that contribute to the often marked interindividual differences in responses to opioid analgesics for patients with postoperative pain. These genetic factors include those affecting analgesic drug metabolism, transport of analgesic agents across the $\mathrm{BBB}$, and their activity at target receptors and ion channels and in the modulation of neurotransmitter pathways. Compared with the multiplicity of routinely identifying a large number of genetic variants, the finding will contribute to the cost reduction in the effort to individualize pain medication. Clinical application of this finding to enable tailoring of analgesic dosing regimens in individual patients is relatively more reachable in the near future. It is important to highlight that identifying the genes encoding opioid receptors, maybe more SNPs of OPRM1, other than metabolizing enzymes, and transporters, will be of great value in clinical settings of postoperative pain control. Still, more clinical studies are necessary to investigate the cost-benefit ratio of this genetic evaluation.

Our meta-analysis has some limitations. Some potential non-genetic factors can modify the effects of genetic SNPs on pain and opioid consumption during the postoperative period, such as age, gender, mood, anxiety, and drug-drug interactions (150). Other factors, such as selective publication bias (i.e., the "winner curse"), may also be a factor. However, little information was provided in most studies on the interactions between such non-genetic factors and SNPs of genetic variant. Therefore, further analyses could not be performed in the present meta-analysis.

\section{Conclusion}

In summary, the present meta-analysis indicated that among the studied genetic SNPs that include those affecting analgesic drug metabolism, transport of analgesic agents across the BBB, and their activity at target receptors and ion channels and in the modulation of neurotransmitter pathways, the A118G allele variant of OPRM1 has more potent influence on pain management of postoperative patients. The $118 \mathrm{G}$ allele reduces the analgesic potency and the occurrence of side effects of opioids, and results in higher pain scores compared with the 118AA homozygotes. The identification of other SNPs of the OPRM1 gene might provide valuable information for clinicians to properly manage the analgesic use of opioids individually for better pain management.

\section{Acknowledgements}

This work is supported by the National Natural Science Foundation of China (No. 81300948), Research Fund for the Doctoral Program of Higher Education by Ministry of Education, China (No. 20120001120072), and Foundation of Peking University Third Hospital, China (2011-BYSY-SEEDFUND, 2013-BYSY-FUND).

\section{References}

1. Mercadante S, Bruera E. Opioid switching: A systematic and critical review. Cancer Treat Rev 2006; 32:304-315.

2. Riley J, Ross JR, Rutter D, Wells AU, Goller K, du Bois R, Welsh K. No pain relief from morphine? Individual variation in sensitivity to morphine and the need to switch to an alternative opioid in cancer patients. Support Care Cancer 2006; 14:56-64.

3. Ross JR, Rutter D, Welsh K, Joel SP, Goller K, Wells AU, Du Bois R, Riley J. Clinical response to morphine in cancer patients and genetic variation in candidate genes. Pharmacogenomics J 2005; 5:324-336.

4. Chou WY, Wang $\mathrm{CH}$, Liu PH, Liu CC, Tseng CC, Jawan B. Human opioid receptor Al18G polymorphism affects intravenous patient-controlled analgesia morphine consumption after total abdominal hysterectomy. Anesthesiology 2006; 105:334-337.

5. Coulbault L, Beaussier M, Verstuyft $C$, Weickmans $H$, Dubert L, Tregouet $D$, Descot C, Parc Y, Lienhart A, Jaillon P,
Becquemont L. Environmental and genetic factors associated with morphine response in the postoperative period. Clin Pharmacol Ther 2006; 79:316-324.

6. Sia AT, Lim Y, Lim EC, Goh RW, Law HY, Landau R, Teo YY, Tan EC. A118G single nucleotide polymorphism of human mu-opioid receptor gene influences pain perception and patient-controlled intravenous morphine consumption after intrathecal morphine for postcesarean analgesia. Anesthesiology 2008; 109:520-526. 
7. Uhl GR, Sora I, Wang Z. The mu opiate receptor as a candidate gene for pain: polymorphisms, variations in expression, nociception, and opiate responses. Proc Natl Acad Sci U S A 1999; 96:7752-7755.

8. Lotsch J, Skarke C, Liefhold J, Geisslinger G. Genetic predictors of the clinical response to opioid analgesics: Clinical utility and future perspectives. Clin Pharmacokinet 2004; 43:983-1013.

9. Sora I, Elmer G, Funada M, Pieper J, Li XF, Hall FS, Uhl GR. Mu opiate receptor gene dose effects on different morphine actions: Evidence for differential in vivo mu receptor reserve. Neuropsychopharmacology 2001; 25:41-54.

10. Ravindranathan A, Joslyn G, Robertson M, Schuckit MA, Whistler JL, White $\mathrm{RL}$. Functional characterization of human variants of the mu-opioid receptor gene. Proc Natl Acad Sci U S A 2009; 106:10811-10816.

11. Yuferov V, Levran O, Proudnikov D, Nielsen DA, Kreek MJ. Search for genetic markers and functional variants involved in the development of opiate and cocaine addiction and treatment. Ann N Y Acad Sci 2010; 1187:184-207.

12. Wang JB, Johnson PS, Persico AM, Hawkins AL, Griffin CA, Uhl GR. Human mu opiate receptor. cDNA and genomic clones, pharmacologic characterization and chromosomal assignment. FEBS Lett 1994; 338:217-222.

13. Bond C, LaForge KS, Tian M, Melia D, Zhang S, Borg L, Gong J, Schluger J, Strong JA, Leal SM, Tischfield JA, Kreek MJ, Yu L. Single-nucleotide polymorphism in the human mu opioid receptor gene alters beta-endorphin binding and activity: Possible implications for opiate addiction. Proc Natl Acad Sci U S A 1998; 95:9608-9613.

14. Fillingim RB, Kaplan L, Staud R, Ness TJ, Glover TL, Campbell CM, Mogil JS, Wallace MR. The A118G single nucleotide polymorphism of the mu-opioid receptor gene (OPRMI) is associated with pressure pain sensitivity in humans. J Pain 2005; 6:159-167.

15. Klepstad P, Rakvag TT, Kaasa S, Holthe $M$, Dale O, Borchgrevink PC, Baar C, Vikan T, Krokan HE, Skorpen F. The $118 \mathrm{~A}>\mathrm{G}$ polymorphism in the human mu-opioid receptor gene may increase morphine requirements in patients with pain caused by malignant disease. Acta Anaesthesiol Scand 2004; 48:1232-1239.

16. Landau R, Kern C, Columb MO, Smiley RM, Blouin JL. Genetic variability of the mu-opioid receptor influences intrathecal fentanyl analgesia requirements in laboring women. Pain 2008; 139:5-14.

17. Reyes-Gibby CC, Shete $S$, Rakvag T, Bhat SV, Skorpen F, Bruera E, Kaasa S, Klepstad P. Exploring joint effects of genes and the clinical efficacy of morphine for cancer pain: OPRM 1 and COMT gene. Pain 2007; 130:25-30.

18. Campa D, Gioia A, Tomei A, Poli P, Barale R. Association of $A B C B 1 / M D R 1$ and $\mathrm{OPRM}$ gene polymorphisms with morphine pain relief. Clin Pharmacol Ther 2008; 83:559-566.

19. Walter C, Lotsch J. Meta-analysis of the relevance of the OPRM $1118 \mathrm{~A}>\mathrm{G}$ genetic variant for pain treatment. Pain 2009; 146:270-275.

20. Chou WY, Yang LC, Lu HF, Ko JY, Wang $\mathrm{CH}$, Lin $\mathrm{SH}$, Lee $\mathrm{TH}$, Concejero A, Hsu C). Association of mu-opioid receptor gene polymorphism (A118G) with variations in morphine consumption for analgesia after total knee arthroplasty. Acto Anaesthesiol Scand 2006; 50:787-792.

21. Liao Q, Chen DJ, Zhang F, Li L, Hu R, Tang YZ, Ou-Yang W, Huang D. Effect of $\mathrm{CYP}_{3} \mathrm{~A}_{4}{ }^{*} 18 \mathrm{~B}$ polymorphisms and interactions with OPRM $A_{118 G}$ on postoperative fentanyl requirements in patients undergoing radical gastrectomy. Molecular Medicine Reports 2013; 7:901-908.

22. Sia AT, Lim Y, Lim EC, Ocampo CE, Lim WY, Cheong P, Tan EC. Influence of muopioid receptor variant on morphine use and self-rated pain following abdominal hysterectomy. J Pain 2013; 14:1045-1052.

23. Zhang F, Liao Q, Li L, Wang SY, Hu R, Tang YZ, Ouyang W. The correlation between post-operative fentanyl requirements and -opioid receptor gene Al18G polymorphism in patients undergoing radical gastrectomy. Exp Ther Med 2013; 5:1147-1152.

24. Zhang W, Chang YZ, Kan QC, Zhang LR, Lu H, Chu QJ, Wang ZY, Li ZS, Zhang J. Association of human micro-opioid receptor gene polymorphism A118G with fentanyl analgesia consumption in Chinese gynaecological patients. Anaesthesia 2010; 65:130-135

25. Zhang W, Yuan JJ, Kan QC, Zhang LR, Chang YZ, Wang ZY. Study of the OPRM1 All8G genetic polymorphism associated with postoperative nausea and vomiting induced by fentanyl intravenous analgesia. Minerva Anestesiol 2011; 77:33-39.

26. Janicki PK, Schuler G, Francis D, Bohr A, Gordin V, Jarzembowski T, Ruiz-Velasco
$\mathrm{V}$, Mets B. A genetic association study of the functional A118G polymorphism of the human mu-opioid receptor gene in patients with acute and chronic pain. Anesth Analg 2006; 103:1011-1017.

27. Zwisler ST, Enggaard TP, Mikkelsen S, Verstuyft C, Becquemont L, Sindrup SH, Brosen K. Lack of Association of OPRM 1 and $A B C B 1$ single-nucleotide polymorphisms to oxycodone response in postoperative pain. J Clin Pharmacol 2012; 52:234-242.

28. Wu WD, Wang Y, Fang YM, Zhou HY. Polymorphism of the micro-opioid receptor gene (OPRM1 $118 \mathrm{~A}>\mathrm{G}$ ) affects fentanyl-induced analgesia during anesthesia and recovery. Mol Diagn Ther 2009; 13:331-337.

29. Henker RA, Lewis A, Dai F, Lariviere WR, Meng L, Gruen GS, Sereika SM, Pape H, Tarkin IS, Gowda I, Conley YP. The associations between OPRM 1 and COMT genotypes and postoperative pain, opioid use, and opioid-induced sedation. Biol Res Nurs 2013; 15:309-317.

30. Fukuda K, Hayashida M, Ikeda K, Koukita Y, Ichinohe T, Kaneko Y. Diversity of opioid requirements for postoperative pain control following oral surgery - is it affected by polymorphism of the mu-opioid receptor? Anesth Prog 2010; 57:145-149.

31. Hayashida $M$, Nagashima $M$, Satoh Y, Katoh R, Tagami M, Ide S, Kasai S, Nishizawa D, Ogai Y, Hasegawa J, Komatsu $\mathrm{H}$, Sora I, Fukuda K, Koga H, Hanaoka K, Ikeda K. Analgesic requirements after major abdominal surgery are associated with $\mathrm{OPRM} 1$ gene polymorphism genotype and haplotype. Pharmacogenomics 2008; 9:1605-1616.

32. Kim KM, Kim HS, Lim SH, Cheong SH, Choi EJ, Kang H, Choi HR, Jeon JW, Yon $J H$, Oh M, Shin JG. Effects of genetic polymorphisms of $\mathrm{OPRM} 1, A B C B 1$, $\mathrm{CYP}_{3} \mathrm{~A}_{4} / 5$ on postoperative fentanyl consumption in Korean gynecologic patients. Int J Clin Pharmacol Ther 2013; 51:383-392.

33. Fukuda K, Hayashida M, Ide S, Saita N, Kokita Y, Kasai S, Nishizawa D, Ogai Y, Hasegawa J, Nagashima M, Tagami M, Komatsu H, Sora I, Koga H, Kaneko Y, Ikeda K. Association between OPRMı gene polymorphisms and fentanyl sensitivity in patients undergoing painful cosmetic surgery. Pain 2009; 147:194-201.

34. De Gregori M, Garbin G, De Gregori S, Minella CE, Bugada D, Lisa A, Govoni S, Regazzi M, Allegri M, Ranzani GN. 
Genetic variability at COMT but not at $\mathrm{OPRM}_{1}$ and $\mathrm{UGT}_{2} \mathrm{~B}_{7}$ loci modulates morphine analgesic response in acute postoperative pain. Eur J Clin Pharmacol 2013; 69:1651-1658.

35. Boswell MV, Stauble ME, Loyd GE, Langman L, Ramey-Hartung B, Baumgartner RN, Tucker WW, Jortani SA. The role of hydromorphone and OPRM 1 in postoperative pain relief with hydrocodone. Pain Physician 2013; 16:E227-E235.

36. Chen LK, Chen SS, Huang $\mathrm{CH}$, Yang HJ, Lin CJ, Chien KL, Fan SZ. Polymorphism of mu-opioid receptor gene (OPRM1:c.118A>G) might not protect against or enhance morphine-induced nausea or vomiting. Pain Res Treat 2013; 2013:259306.

37. Nelson DR. Cytochrome P450 nomenclature, 2004. Methods Mol Biol 2006; 320:1-10.

38. Tan EC, Lim EC, Teo YY, Lim Y, Law HY, Sia AT. Ethnicity and OPRM variant independently predict pain perception and patient-controlled analgesia usage for post-operative pain. Mol Pain 2009; 5:32.

39. Crist RC, Berrettini WH. Pharmacogenetics of OPRM1. Pharmacol Biochem Behav 2014; 123:25-33.

40. Adler TK, Fujimoto JM, Way EL, Baker EM. The metabolic fate of codeine in man. J Pharmacol Exp Ther 1955; 114:251-262.

41. Pert CB, Snyder SH. Properties of opiate-receptor binding in rat brain. Proc Natl Acad Sci U S A 1973; 70:2243-2247.

42. Manini AF, Jacobs MM, Vlahov D, Hurd YL. Opioid receptor polymorphism A118G associated with clinical severity in a drug overdose population. J Med Toxicol 2013; 9:148-154.

43. Ziesenitz VC, van den Anker JN. Impact of $\mathrm{CYP}_{3} \mathrm{~A}$ and $\mathrm{ABCB}$ 1 polymorphisms on the pharmacokinetics and pharmacodynamics of fentanyl. Int ] Clin Pharmacol Ther 2013; 51:991-992.

44. Feierman DE, Lasker JM. Metabolism of fentanyl, a synthetic opioid analgesic, by human liver microsomes. Role of $\mathrm{CYP}_{3} \mathrm{~A}_{4}$. Drug Metab Dispos 1996; 24:932-939.

45. Chen YT, Tsou HH, Kuo HW, Fang CP, Wang SC, Ho IK, Chang YS, Chen $\mathrm{CH}$, Hsiao CF, Wu HY, Lin KM, Chen A, TsaiWu JJ, Liu YL. OPRMı genetic polymorphisms are associated with the plasma nicotine metabolite cotinine concentration in methadone maintenance patients: A cross sectional study. J Hum
Genet 2013; 58:84-90.

46. Gaedigk A, Simon SD, Pearce RE, Bradford LD, Kennedy MJ, Leeder JS. The $\mathrm{CYP}_{2} \mathrm{D} 6$ activity score: Translating genotype information into a qualitative measure of phenotype. Clinical Pharmacology and Therapeutics 2008; 83:234-242.

47. Persson K, Sjostrom S, Sigurdardottir I, Molnar V, Hammarlund-Udenaes $M$, Rane A. Patient-controlled analgesia (PCA) with codeine for postoperative pain relief in ten extensive metabolisers and one poor metaboliser of dextromethorphan. Br J Clin Pharmacol 1995; 39:182-186.

48. VanderVaart $\mathrm{S}$, Berger $\mathrm{H}$, Sistonen J, Madadi P, Matok I, Gijsen VM, de Wildt SN, Taddio A, Ross CJ, Carleton BC, Hayden MR, Koren G. CYP2D6 polymorphisms and codeine analgesia in postpartum pain management: A pilot study. Ther Drug Monit 2011; 33:425-432.

49. Ochroch EA, Vachani A, Gottschalk A, Kanetsky PA. Natural variation in the mu-opioid gene OPRM predicts increased pain on third day after thoracotomy. Clin J Pain 2012; 28:747-754.

50. Rauers NI, Stuber F, Lee EH, Musshoff F, Fimmers R, Barann M, Stamer UM. Antagonistic effects of ondansetron and tramadol? A randomized placebo and active drug controlled study. J Pain 2010; 11:1274-1281.

51. Slanar O, Dupal P, Matouskova O, Vondrackova H, Pafko P, Perlik F. Tramadol efficacy in patients with postoperative pain in relation to $\mathrm{CYP}_{2} \mathrm{D} 6$ and $M \mathrm{MR}_{1}$ polymorphisms. Bratisl Lek Listy 2012; 113:152-155.

52. Candiotti KA, Yang $Z$, Rodriguez $Y$, Crescimone A, Sanchez GC, Takacs P, Medina C, Zhang Y, Liu H, Gitlin MC. The impact of $\mathrm{CYP}_{2} \mathrm{D} 6$ genetic polymorphisms on postoperative morphine consumption. Pain Med 2009; 10:799-805.

53. Zwisler ST, Enggaard TP, Mikkelsen S, Brosen $\mathrm{K}$, Sindrup $\mathrm{SH}$. Impact of the CYP2D6 genotype on post-operative intravenous oxycodone analgesia. Acto Anaesthesiol Scand 2010; 54:232-240.

54. Preston KL, Jasinski DR, Testa M. Abuse potential and pharmacological comparison of tramadol and morphine. Drug Alcohol Depend 1991; 27:7-17.

55. Vickers MD, O'Flaherty D, Szekely SM, Read M, Yoshizumi J. Tramadol: Pain relief by an opioid without depression of respiration. Anaesthesia 1992; 47:291-296.

56. Paar WD, Poche S, Gerloff J, Dengler $\mathrm{HJ}$. Polymorphic CYP2D6 mediates O- demethylation of the opioid analgesic tramadol. Eur J Clin Pharmacol 1997; 53:235-239.

57. Poulsen L, Arendt-Nielsen L, Brosen K, Sindrup $\mathrm{SH}$. The hypoalgesic effect of tramadol in relation to $\mathrm{CYP}_{2} \mathrm{D} 6$. Clin Pharmacol Ther 1996; 60:636-644.

58. Gasche Y, Daali Y, Fathi M, Chiappe A, Cottini S, Dayer P, Desmeules J. Codeine intoxication associated with ultrarapid CYP2D6 metabolism. $N$ Engl] Med 2004; 351:2827-2831.

59. Stamer UM, Lehnen $K$, Hothker $F$, Bayerer B, Wolf S, Hoeft A, Stuber F. Impact of $\mathrm{CYP}_{2} \mathrm{D} 6$ genotype on postoperative tramadol analgesia. Pain 2003; 105:231-238.

6o. Zhu W, Cadet P, Baggerman G, Mantione KJ, Stefano GB. Human white blood cells synthesize morphine: $\mathrm{CY}$ P2D6 modulation. J Immunol 2005; 175:7357-7362.

61. Yuan R, Zhang $X$, Deng $Q, W u Y$, Xiang G. Impact of $\mathrm{CYP}_{3} \mathrm{~A}_{4} \star_{1} \mathrm{G}$ polymorphism on metabolism of fentanyl in Chinese patients undergoing lower abdominal surgery. Clinica Chimica Acta; International Journal of Clinical Chemistry 2011; 412:755-760.

62. Zhang W, Yuan JJ, Kan QC, Zhang LR, Chang YZ, Wang ZY, Li ZS. Influence of $\mathrm{CYP}_{3} \mathrm{~A}_{5}{ }_{3}$ polymorphism and interaction between $\mathrm{CYP}_{3} \mathrm{~A}_{5}{ }_{3}$ and $\mathrm{CYP}_{3} \mathrm{~A}_{4}{ }_{1} \mathrm{G}$ polymorphisms on post-operative fentanyl analgesia in Chinese patients undergoing gynaecological surgery. European Journal of Anaesthesiology 2011; 28:245-250.

63. Dong ZL, Li H, Chen QX, Hu Y, Wu SJ, Tang LY, Gong WY, Xie GH, Fang XM. Effect of $\mathrm{CYP}_{3} \mathrm{~A}_{4}{ }_{1} \mathrm{G}$ on the fentanyl consumption for intravenous patientcontrolled analgesia after total abdominal hysterectomy in Chinese Han population. Journal of Clinical Pharmacy and Therapeutics 2012; 37:153-156.

64. Tan PC, Hassan SK, Mohamad NA, Gan $\mathrm{SH}$. Cytochrome $\mathrm{P}_{45}{ }_{3} \mathrm{~A}_{4}$ genetic polymorphisms and post-operative fentanyl requirements. J Clin Pharm Ther 2012; 37:100-104.

65. Labroo RB, Paine MF, Thummel KE, Kharasch ED. Fentanyl metabolism by human hepatic and intestinal cytochrome P450 3A4: Implications for interindividual variability in disposition, efficacy, and drug interactions. Drug Metabolism and Disposition: The Biological Fate of Chemicals 1997; 25:1072-1080.

66. Liu CH, Peck K, Huang JD, Lin MS, 
Wang $\mathrm{CH}$, Hsu WP, Wang HW, Lee HL, Lai ML. Screening $\mathrm{CYP}_{3} \mathrm{~A}$ single nucleotide polymorphisms in a Han Chinese population with a genotyping chip. Pharmacogenomics 2005; 6:731-747.

67. Du J, Yu L, Wang L, Zhang A, Shu A, Xu L, Xu M, Shi Y, Li X, Feng G, Xing Q, He L. Differences in $\mathrm{CYP}_{3} \mathrm{~A}_{41} \mathrm{G}$ genotype distribution and haplotypes of $\mathrm{CYP}_{3} \mathrm{~A}_{4}$, $\mathrm{CYP}_{3} \mathrm{~A}_{5}$ and $\mathrm{CYP}_{3} \mathrm{~A}_{7}$ in 3 Chinese populations. Clin Chim Acta 2007; 383:172-174.

68. Wang $G$, Zhang $H$, He F, Fang X. Effect of the CYP2D6* ${ }_{10} \mathrm{C}_{1} 88 \mathrm{~T}$ polymorphism on postoperative tramadol analgesia in a Chinese population. Eur J Clin Pharmacol 2006; 62:927-931.

69. Beaver WT, Wallenstein SL, Rogers A, Houde RW. Analgesic studies of codeine and oxycodone in patients with cancer. I. Comparisons of oral with intramuscular codeine and of oral with intramuscular oxycodone. J Pharmacol Exp Ther 1978; 207:92-100.

70. Wesmiller SW, Henker RA, Sereika SM, Donovan HS, Meng L, Gruen GS, Tarkin IS, Conley YP. The association of CY$\mathrm{P}_{2} \mathrm{D} 6$ genotype and postoperative nausea and vomiting in orthopedic trauma patients. Biol Res Nurs 2013; 15:382-389.

71. Ozdemir V, Kalow W, Tang BK, Paterson $A D$, Walker SE, Endrenyi L, Kashuba AD. Evaluation of the genetic component of variability in $\mathrm{CYP}_{3} \mathrm{~A}_{4}$ activity: $\mathrm{A}$ repeated drug administration method. Pharmacogenetics 2000; 10:373-388.

72. Evans WE, McLeod HL. Pharmacogenomics - drug disposition, drug targets, and side effects. N Engl J Med 2003; 348:538-549.

73. Zhang W, Chang YZ, Kan QC, Zhang LR, Li ZS, Lu H, Wang ZY, Chu QJ, Zhang J. $\mathrm{CYP}_{3} \mathrm{~A}_{4}{ }_{1} \mathrm{G}$ genetic polymorphism influences $\mathrm{CYP}_{3} \mathrm{~A}$ activity and response to fentanyl in Chinese gynecologic patients. European Journal of Clinical Pharmacology 2010; 66:61-66.

74. Fukushima-Uesaka H, Saito $Y$, Watanabe $\mathrm{H}$, Shiseki K, Saeki M, Nakamura T, Kurose K, Sai K, Komamura K, Ueno K, Kamakura S, Kitakaze $M$, Hanai $S$, Nakajima T, Matsumoto K, Saito $H$, Goto Y, Kimura H, Katoh M, Sugai K, Minami N, Shirao K, Tamura T, Yamamoto N, Minami H, Ohtsu A, Yoshida T, Saijo N, Kitamura Y, Kamatani N, Ozawa $\mathrm{S}$, Sawada J. Haplotypes of $\mathrm{CYP}_{3} \mathrm{~A}_{4}$ and their close linkage with $\mathrm{CYP}_{3} \mathrm{~A}_{5}$ haplotypes in a Japanese population. Hum Mutat 2004; 23:100.

75. Hu YF, Tu JH, Tan ZR, Liu ZQ, Zhou G, He J, Wang D, Zhou HH. Association of $\mathrm{CYP}_{3} \mathrm{~A}_{4}{ }_{1} 8 \mathrm{~B}$ polymorphisms with the pharmacokinetics of cyclosporine in healthy subjects. Xenobiotica 2007; 37:315-327.

76. Zanger UM, Schwab M. Cytochrome P450 enzymes in drug metabolism: Regulation of gene expression, enzyme activities, and impact of genetic variation. Pharmacol Ther 2013; 138:103-141.

77. Hu YF, He J, Chen GL, Wang D, Liu ZQ, Zhang C, Duan LF, Zhou HH. $\mathrm{CYP}_{3} \mathrm{~A}_{5}{ }_{3}$ and $\mathrm{CYP}_{3} \mathrm{~A}_{4}{ }_{1} 8$ single nucleotide polymorphisms in a Chinese population. $\mathrm{Cl}$ inica Chimica Acta; International Journal of Clinical Chemistry 2005; 353:187-192.

78. Yousef AM, Bulatova NR, Newman W, Hakooz N, Ismail S, Qusa H, Zahran F, Anwar Ababneh N, Hasan F, Zaloom I, Khayat G, Al-Zmili R, Naffa R, Al-Diab O. Allele and genotype frequencies of the polymorphic cytochrome $\mathrm{P}_{450}$ genes $\left(\mathrm{CYP}_{1} \mathrm{~A}_{1}, \mathrm{CYP}_{3} \mathrm{~A}_{4}, \mathrm{CYP}_{3} \mathrm{~A}_{5}, \mathrm{CYP}_{2} \mathrm{C}_{9}\right.$ and $\left.\mathrm{CYP}_{2} \mathrm{C}_{19}\right)$ in the Jordanian population. Mol Biol Rep 2012; 39:9423-9433.

79. Lee SJ, Lee SS, Jeong HE, Shon JH, Ryu JY, Sunwoo YE, Liu KH, Kang W, Park YJ, Shin CM, Shin JG. The CYP3A4 $\mathrm{A}_{4} 18$ allele, the most frequent coding variant in asian populations, does not significantly affect the midazolam disposition in heterozygous individuals. Drug Metab Dispos 2007; 35:2095-2101.

8o. Lotsch J, Schmidt R, Vetter G, Schmidt $H$, Niederberger E, Geisslinger G, Tegeder I. Increased CNS uptake and enhanced antinociception of morphine6-glucuronide in rats after inhibition of P-glycoprotein. J Neurochem 2002; 83:241-248.

81. Rakvag TT, Ross JR, Sato H, Skorpen F, Kaasa S, Klepstad P. Genetic variation in the catechol-O-methyltransferase (COMT) gene and morphine requirements in cancer patients with pain. Mol Pain 2008; 4:64

82. Somogyi AA, Barratt DT, Coller JK. Pharmacogenetics of opioids. Clin Pharmacol Ther 2007; 81:429-444.

83. Cascorbi I, Gerloff T, Johne A, Meisel C, Hoffmeyer S, Schwab M, Schaeffeler E, Eichelbaum M, Brinkmann U, Roots I. Frequency of single nucleotide polymorphisms in the P-glycoprotein drug transporter MDRı gene in white subjects. Clin Pharmacol Ther 2001; 69:169-174.

84. Crettol S, Deglon JJ, Besson J, Croquette-Krokar M, Hammig R, Gothuey I, Monnat M, Eap CB. ABCBı and cytochrome $\mathrm{P}_{450}$ genotypes and phenotypes: Influence on methadone plasma levels and response to treatment. Clin Pharmacol Ther 2006; 80:668-681.

85. Lotsch J, Geisslinger G, Tegeder I. Genetic modulation of the pharmacological treatment of pain. Pharmacol Ther 2009; 124:168-184.

86. Sia AT, Sng BL, Lim EC, Law H, Tan EC. The influence of ATP-binding cassette sub-family $B$ member $-1(A B C B 1)$ genetic polymorphisms on acute and chronic pain after intrathecal morphine for caesarean section: A prospective cohort study. Int J Obstet Anesth 2010; 19:254-260.

87. Mamie C, Rebsamen MC, Morris MA, Morabia A. First evidence of a polygenic susceptibility to pain in a pediatric cohort. Anesth Analg 2013; 116:170-177.

88. Candiotti K, Yang Z, Xue L, Zhang Y, Rodriguez $Y$, Wang L, Hao S, Gitlin M. Single-nucleotide polymorphism $\mathrm{C}_{3435} \mathrm{~T}$ in the $A B C B 1$ gene is associated with opioid consumption in postoperative pain. Pain Med 2013; 14:1977-1984.

89. Choi EM, Lee MG, Lee SH, Choi KW, Choi SH. Association of ABCBı polymorphisms with the efficacy of ondansetron for postoperative nausea and vomiting. Anaesthesia 2010; 65:996-1000.

9o. Matouskova O, Slanar O, Adamkova J, Pafko P, Perlik F, Adamek S. Impact of MDRı genetic polymorphisms on postoperative piritramide analgesia. Bratisl Lek Listy 2013; 114:133-135.

91. Grossman MH, Emanuel BS, Budarf ML. Chromosomal mapping of the human catechol-O-methyltransferase gene to 22q11.1-q11.2. Genomics 1992; 12:822-825.

92. Lachman HM, Morrow B, Shprintzen R, Veit S, Parsia SS, Faedda G, Goldberg R, Kucherlapati R, Papolos DF. Association of codon 108/158 catechol-O-methyltransferase gene polymorphism with the psychiatric manifestations of velocardio-facial syndrome. Am J Med Genet 1996; 67:468-472.

93. Mannisto PT, Kaakkola S. Catechol-Omethyltransferase (COMT): Biochemistry, molecular biology, pharmacology, and clinical efficacy of the new selective COMT inhibitors. Pharmacol Rev 1999; 51:593-628.

94. Diatchenko L, Slade GD, Nackley AG, Bhalang K, Sigurdsson A, Belfer I, Goldman D, Xu K, Shabalina SA, Shagin D, Max MB, Makarov SS, Maixner W. Genetic basis for individual variations in pain perception and the development of a chronic pain condition. Hum Mol Genet 2005; 14:135-143. 
95. Nackley AG, Tan KS, Fecho K, Flood P, Diatchenko L, Maixner W. Catechol-Omethyltransferase inhibition increases pain sensitivity through activation of both beta2- and beta3-adrenergic receptors. Pain 2007; 128:199-208.

96. Lotta T, Vidgren J, Tilgmann C, Ulmanen I, Melen K, Julkunen I, Taskinen J. Kinetics of human soluble and membranebound catechol O-methyltransferase: A revised mechanism and description of the thermolabile variant of the enzyme. Biochemistry 1995; 34:4202-4210.

97. Kambur O, Mannisto PT. Catechol-Omethyltransferase and pain. Int Rev Neurobiol 2010; 95:227-279.

98. van Meurs JB, Uitterlinden AG, Stolk L, Kerkhof HJ, Hofman A, Pols HA, Bierma-Zeinstra SM. A functional polymorphism in the catechol-O-methyltransferase gene is associated with osteoarthritis-related pain. Arthritis Rheum 2009; 60:628-629.

99. Diatchenko L, Nackley AG, Slade GD, Bhalang K, Belfer I, Max MB, Goldman D, Maixner W. Catechol-O-methyltransferase gene polymorphisms are associated with multiple pain-evoking stimuli. Pain 2006; 125:216-224.

100. Lemonde S, Turecki G, Bakish D, Du L, Hrdina PD, Bown CD, Sequeira A, Kushwaha N, Morris SJ, Basak A, Ou $X M$, Albert PR. Impaired repression at a 5-hydroxytryptamine $\mathrm{IA}$ receptor gene polymorphism associated with major depression and suicide. J Neurosci 2003; 23:8788-8799.

101. Albert PR, Lemonde S. 5-HT1A receptors, gene repression, and depression: Guilt by association. Neuroscientist 2004; 10:575-593.

102. Parsey RV, Olvet DM, Oquendo MA, Huang YY, Ogden RT, Mann JJ. Higher $5-\mathrm{HT}_{1} \mathrm{~A}$ receptor binding potential during a major depressive episode predicts poor treatment response: Preliminary data from a naturalistic study. Neuropsychopharmacology 2006; 31:1745-1749.

103. Serretti A, Mandelli L, Giegling I, Schneider B, Hartmann AM, Schnabel A, Maurer K, Moller HJ, Rujescu D. $\mathrm{HTR}_{2} \mathrm{C}$ and $\mathrm{HTR}_{1} \mathrm{~A}$ gene variants in German and Italian suicide attempters and completers. Am J Med Genet B Neuropsychiatr Genet 2007; 144B:291-299.

104. Yu YW, Tsai SJ, Liou YJ, Hong CJ, Chen TJ. Association study of two serotonin $\mathrm{IA}$ receptor gene polymorphisms and fluoxetine treatment response in Chinese major depressive disorders. Eur Neuropsychopharmacol 2006; 16:498-503.
105. Mico JA, Berrocoso E, Ortega-Alvaro A, Gibert-Rahola J, Rojas-Corrales MO. The role of ${ }_{5}-\mathrm{HT}_{1} \mathrm{~A}$ receptors in research strategy for extensive pain treatment. Curr Top Med Chem 2006; 6:1997-2003.

106. Colpaert FC. $5-\mathrm{HT}(\mathrm{IA})$ receptor activation: New molecular and neuroadaptive mechanisms of pain relief. Curr Opin Investig Drugs 2006; 7:40-47.

107. Chen K, Yang W, Grimsby J, Shih JC. The human $5-\mathrm{HT}_{2}$ receptor is encoded by a multiple intron-exon gene. Brain Res Mol Brain Res 1992; 14:20-26.

108. Campbell DA, Sundaramurthy D, Markham AF, Pieri LF. Fine mapping of the human 5-HTR2a gene to chromosome 13914 and identification of two highly polymorphic linked markers suitable for association studies in psychiatric disorders. Genet Test 1997; 1:297-299.

109. Kato M, Serretti A. Review and metaanalysis of antidepressant pharmacogenetic findings in major depressive disorder. Mol Psychiatry 2010; 15:473-500.

110. Abbott FV, Hong Y, Blier P. Activation of $5-\mathrm{HT}_{2} \mathrm{~A}$ receptors potentiates pain produced by inflammatory mediators. Neuropharmacology 1996; 35:99-110.

111. Tokunaga A, Saika M, Senba E. 5- $\mathrm{HT}_{2} \mathrm{~A}$ receptor subtype is involved in the thermal hyperalgesic mechanism of serotonin in the periphery. Pain 1998; 76:349-355.

112. Bondy B, Spaeth $M$, Offenbaecher $M$, Glatzeder K, Stratz T, Schwarz M, de Jonge $S$, Kruger M, Engel RR, Farber L, Pongratz DE, Ackenheil M. The $\mathrm{T}_{102} \mathrm{C}$ polymorphism of the $5-\mathrm{HT}_{2} \mathrm{~A}$-receptor gene in fibromyalgia. Neurobiol Dis 1999; 6:433-439.

113. Gursoy S, Erdal E, Herken H, Madenci $\mathrm{E}$, Alasehirli B. Association of $\mathrm{T}_{102} \mathrm{C}$ polymorphism of the $5-\mathrm{HT}_{2} \mathrm{~A}$ receptor gene with psychiatric status in fibromyalgia syndrome. Rheumatol Int 2001; 21:58-61.

114. Saito YA, Cremonini F, Talley NJ. Association of the 1438G/A and 102T/C polymorphism of the $5-\mathrm{HT}_{2} \mathrm{~A}$ receptor gene with irritable bowel syndrome $5-\mathrm{HT}_{2} \mathrm{~A}$ gene polymorphism in irritable bowel syndrome. J Clin Gastroenterol 2005; 39:835; author reply 835-836.

115. Aoki J, Hayashida M, Tagami M, Nagashima M, Fukuda K, Nishizawa D, Ogai Y, Kasai S, Ikeda K, Iwahashi K. Association between 5 -hydroxytryptamine $2 \mathrm{~A}$ receptor gene polymorphism and postoperative analgesic requirements after major abdominal surgery. Neurosci Lett 2010; 479:40-43.
116. Reichling DB, Green PG, Levine JD. The fundamental unit of pain is the cell. Pain 2013; 154 Suppl 1:S2-S9.

117. Dubin AE, Patapoutian A. Nociceptors: The sensors of the pain pathway. J Clin Invest 2010; 120:3760-3772.

118. Bennett DL, Woods CG. Painful and painless channelopathies. Lancet Neurol 2014; 13:587-599.

119. Willis WD, Jr. The role of TRPV 1 receptors in pain evoked by noxious thermal and chemical stimuli. Exp Brain Res 2009; 196:5-11.

120. Caterina MJ, Schumacher MA, Tominaga $M$, Rosen TA, Levine JD, Julius D. The capsaicin receptor: a heat-activated ion channel in the pain pathway. Nature 1997; 389:816-824.

121. Xu H, Tian W, Fu Y, Oyama TT, Anderson $S$, Cohen DM. Functional effects of nonsynonymous polymorphisms in the human TRPVı gene. Am ] Physiol Renal Physiol 2007; 293:F1865-F1876.

122. Khairatkar-Joshi N, Szallasi A. TRPV 1 antagonists: The challenges for therapeutic targeting. Trends Mol Med 2009; 15:14-22.

123. Bevan S, Andersson DA. TRP channel antagonists for pain - opportunities beyond TRPV1. Curr Opin Investig Drugs 2009; 10:655-663.

124. Toledo-Aral JJ, Moss BL, He ZJ, Koszowski AG, Whisenand T, Levinson SR, Wolf J, Silos-Santiago I, Halegoua S, Mandel G. Identification of $\mathrm{PN}$, a predominant voltage-dependent sodium channel expressed principally in peripheral neurons. Proc Natl Acad Sci U S A 1997; 94:1527-1532.

125. Akopian AN, Sivilotti L, Wood JN. A tetrodotoxin-resistant voltage-gated sodium channel expressed by sensory neurons. Nature 1996; 379:257-262.

126. Dib-Hajj SD, Tyrrell L, Black JA, Waxman SG. $\mathrm{NaN}$, a novel voltage-gated $\mathrm{Na}$ channel, is expressed preferentially in peripheral sensory neurons and downregulated after axotomy. Proc Natl Acad Sci U S A 1998; 95:8963-8968.

127. Cox JJ, Reimann F, Nicholas AK, Thornton G, Roberts E, Springell K, Karbani G, Jafri H, Mannan J, Raashid Y, AlGazali L, Hamamy H, Valente EM, Gorman S, Williams R, McHale DP, Wood JN, Gribble FM, Woods CG. An SCNgA channelopathy causes congenital inability to experience pain. Nature 2006; 444:894-898.

128. Ahmad $S$, Dahllund $L$, Eriksson $A B$, Hellgren D, Karlsson U, Lund PE, Meijer IA, Meury L, Mills T, Moody A, Morin- 
ville A, Morten J, O'Donnell D, Raynoschek C, Salter H, Rouleau GA, Krupp JJ. A stop codon mutation in $\mathrm{SCN}_{9}$ A causes lack of pain sensation. Hum Mol Genet 2007; 16:2114-2121.

129. Rush AM, Dib-Hajj SD, Liu S, Cummins TR, Black JA, Waxman SG. A single sodium channel mutation produces hyperor hypoexcitability in different types of neurons. Proc Natl Acad Sci U S A 2006; 103:8245-8250.

130. Drenth JP, te Morsche RH, Guillet G, Taieb A, Kirby RL, Jansen JB. SCNgA mutations define primary erythermalgia as a neuropathic disorder of voltage gated sodium channels. J Invest Dermatol 2005; 124:1333-1338.

131. Fertleman CR, Baker MD, Parker KA, Moffatt S, Elmslie FV, Abrahamsen B, Ostman J, Klugbauer N, Wood JN, Gardiner RM, Rees M. SCN9A mutations in paroxysmal extreme pain disorder: Allelic variants underlie distinct channe defects and phenotypes. Neuron 2006; 52:767-774.

132. Yuan R, Zhang X, Deng Q, Si D, Wu Y, Gao F, Zhou B. Two novel SCN9A gene heterozygous mutations may cause partial deletion of pain perception. Pain Med 2011; 12:1510-1514.

133. Duan G, Xiang G, Zhang X, Yuan R, Zhan $H$, Qi D. A single-nucleotide polymorphism in $\mathrm{SCN}_{9} \mathrm{~A}$ may decrease postoperative pain sensitivity in the general population. Anesthesiology 2013; 118:436-442.

134. Laulin JP, Celerier E, Larcher A, Le Moal $M$, Simonnet $G$. Opiate tolerance to daily heroin administration: An apparent phenomenon associated with enhanced pain sensitivity. Neuroscience 1999; 89:631-636.

135. White JM. Pleasure into pain: The consequences of long-term opioid use. Addict Behav 2004; 29:1311-1324.

136. Celerier E, Laulin JP, Corcuff JB, Le Moal M, Simonnet G. Progressive enhancement of delayed hyperalgesia induced by repeated heroin administration: A sensitization process. ] Neurosci 2001; 21:4074-4080.

137. Swarm RA, Abernethy AP, Anghelescu DL, Benedetti C, Buga S, Cleeland C, Deleon-Casasola OA, Eilers JG, Ferrell B, Green M, Janjan NA, Kamdar MM, Levy $\mathrm{MH}$, Lynch M, McDowell RM, Moryl N, Nesbit SA, Paice JA, Rabow MW, Syrjala KL, Urba SG, Weinstein SM, Dwyer M, Kumar R. Adult cancer pain. J Natl Compr Canc Netw 2013; 11:992-1022.

138. Song Z, Du B, Wang K, Shi X. Effects of $\mathrm{OPRM}_{1}$ Al18G polymorphism on epidural analgesia with fentanyl during labor: A meta-analysis. Genet Test Mol Biomarkers 2013; 17:743-749.

139. Hwang IC, Park JY, Myung SK, Ahn HY, Fukuda K, Liao Q. OPRMı Aı18G gene variant and postoperative opioid requirement: A systematic review and meta-analysis. Anesthesiology 2014; 121:825-834.

140. Beyer A, Koch T, Schroder H, Schulz S, Hollt V. Effect of the Al18G polymorphism on binding affinity, potency and agonist-mediated endocytosis, desensitization, and resensitization of the human mu-opioid receptor. J Neurochem 2004; 89:553-560.

141. Margas W, Zubkoff I, Schuler HG, Janicki PK, Ruiz-Velasco V. Modulation of $\mathrm{Ca2}+$ channels by heterologously expressed wild-type and mutant human micro-opioid receptors (hMORs) containing the A118G single-nucleotide polymorphism. J Neurophysiol 2007; 97:1058-1067.

142. Zhang $Y$, Wang D, Johnson AD, Papp AC, Sadee W. Allelic expression imbalance of human mu opioid receptor (OPRMl) caused by variant A118G. J Biol Chem 2005; 280:32618-32624.

143. Elmer GI, Pieper JO, Negus SS, Woods $\mathrm{JH}$. Genetic variance in nociception and its relationship to the potency of morphine-induced analgesia in thermal and chemical tests. Pain 1998; 75:129-140.

144. Mogil JS, Wilson SG, Bon K, Lee SE,
Chung K, Raber P, Pieper JO, Hain HS, Belknap JK, Hubert L, Elmer GI, Chung JM, Devor M. Heritability of nociception II. 'Types' of nociception revealed by genetic correlation analysis. Pain 1999; 80:83-93.

145. Mogil JS, Sternberg WF, Marek P, Sadowski B, Belknap JK, Liebeskind JC. The genetics of pain and pain inhibition. Proc Natl Acad Sci U S A 1996; 93:3048-3055.

146. Oertel BG, Schmidt R, Schneider A, Geisslinger $\mathrm{G}$, Lotsch J. The mu-opioid receptor gene polymorphism $118 \mathrm{~A}>\mathrm{G}$ depletes alfentanil-induced analgesia and protects against respiratory depression in homozygous carriers. Pharmacogenet Genomics 2006; 16:625-636.

147. Romberg R, Olofsen E, Sarton E, Teppema L, Dahan A. Pharmacodynamic effect of morphine-6-glucuronide versus morphine on hypoxic and hypercapnic breathing in healthy volunteers. Anesthesiology 2003; 99:788-798.

148. Lotsch J, Skarke C, Grosch S, Darimont J, Schmidt $H$, Geisslinger $G$. The polymorphism Al18G of the human mu-opioid receptor gene decreases the pupil constrictory effect of morphine-6-glucuronide but not that of morphine. Pharmacogenetics 2002; 12:3-9.

149. Skarke C, Darimont J, Schmidt H, Geisslinger G, Lotsch J. Analgesic effects of morphine and morphine-6-glucuronide in a transcutaneous electrical pain model in healthy volunteers. Clin Pharmacol Ther 2003; 73:107-121.

150. Yang JC, Clark WC, Tsui SL, Ng KF, Clark SB. Preoperative Multidimensional Affect and Pain Survey (MAPS) scores predict postcolectomy analgesia requirement. Clin J Pain 2000; 16:314-320.

151. Kolesnikov Y, Gabovits B, Levin A, Voiko E, Veske A. Combined catechol-O-methyltransferase and mu-opioid receptor gene polymorphisms affect morphine postoperative analgesia and central side effects. Anesth Analg 2011; 112:448-453. 